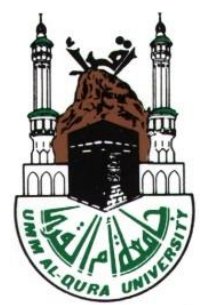

$$
\text { كلية الدعوة وأصول الدين }
$$

\title{
التجريد في القرآن الكريم دراسة تفسيريّة
}

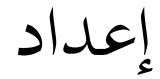

$$
\begin{aligned}
& \text { د. إبراهيم بن عبل الله الزهراني } \\
& \text { الأستاذ المشارك بقسم القراءات }
\end{aligned}
$$




\section{ملخص البحث}

يُعنى هذا البحث بدراسة أسلوب من أساليب البلاغة العربية -البديع على وجه الخصوص-، وهو ( التجريد )، وذلك من خلال تعريفه لغة واصطلاحًا، وبيان قيمته البلاغيّة، وعلاقته بالقرآن

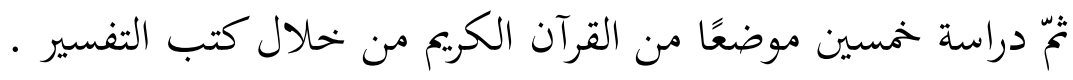

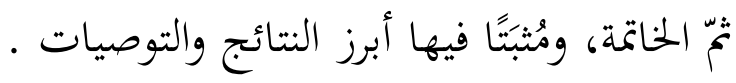




\section{ملخص البحث}

\section{باللغة الإنجليزية}

Research Summary:

This research follows with Al-Badeea ( Rhetorical Embellishment), an Arabic rhetoric method, and more specifically follows with the method of Al-Tajreed (Abstraction), by defining it, introducing its rhetorical value, and finally by conducting a study on fifty different places found in Quran through works of tafseer (Quran Interpretation. Lastly, the study ends with a conclusion, results and recommendations. 


$$
\text { بسم الله الرحمن الرحيم }
$$

الحمد لله الذي قهرت حجته كلّ حجة، وأعجز بيان كتابه كلّ بيان، والصلاة والسلام على سيدنا محمد أفصح من نطق بالضاد، وعلى آله وأصحابه الذين نقلوا إلينا كتاب الله وسنّة رسوله، بـانه ومن تبعهم بإحسان إلى يوم الدين، وبعد:

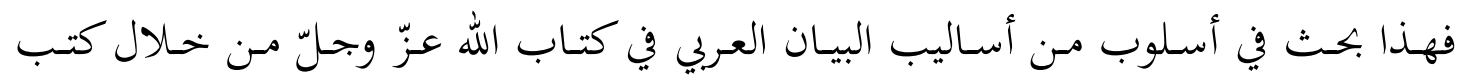
التفسير، وعنوانه: - مان 》التجريد في القرآن الكريم؛ دراسة تفسيريّة - تعريف التجريد لغةً واصطلاحًا . - ق قيمة التجريد البلاغيّة . - - علاقة التجريد بالقرآن الكريم. - مراسة تطبيقيّة للتجريد في القرآن الكريم .

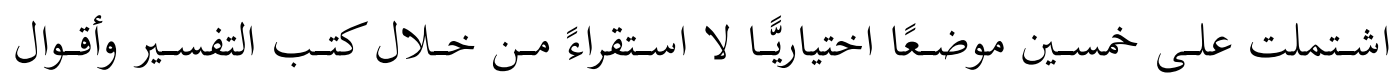

$$
\text { · المفسّرين }
$$

$$
\text { - الخاتمة، وفيها أبرز النتائج والتوصيات · - }
$$

أسأل الله التوفيق، وأن ينفع بما في هذا البحث، وهو أكرم مسؤول .. 


\section{تعريف ( التجريد ) لغةً واصطلاحًا}

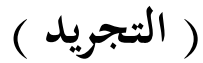

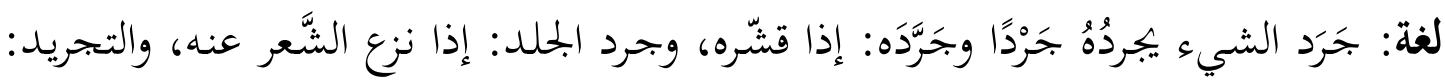

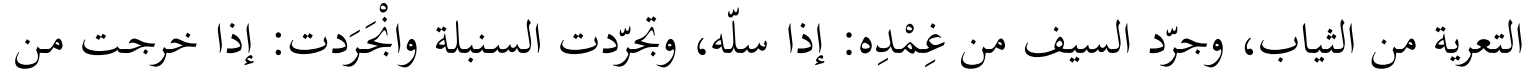

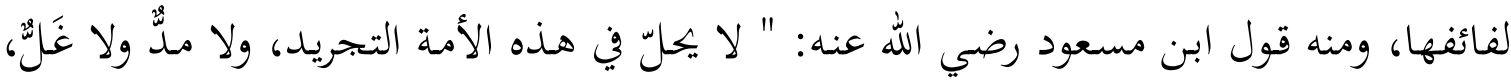

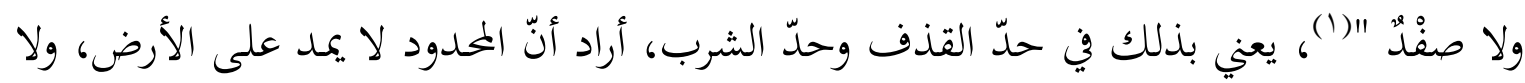

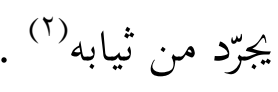

اصطلاححًا: للتجريد عند علماء البلاغة تعريفان: الأول: ما ذكره القزويني: "بأنّ التجريد هو أن ينتزع من أمر ذي صفة آخر مثله فيها؛ مبالغةً

$$
\text { لكمالها فيه "(r) (") }
$$

الثاني: ما ذكر ابن الأثير: " بأنّ التجريد هو إخلاص الخطاب لغيرك، وأنت تريد به نفسك،

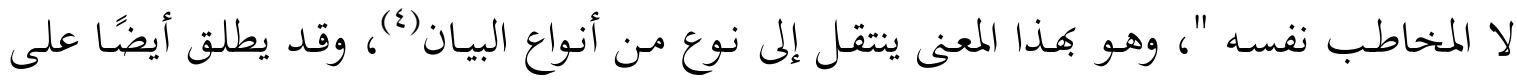

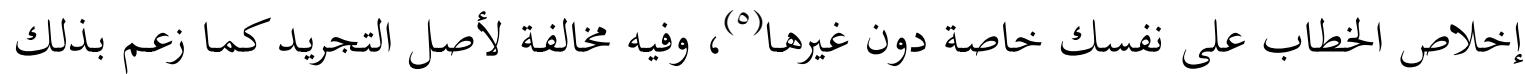

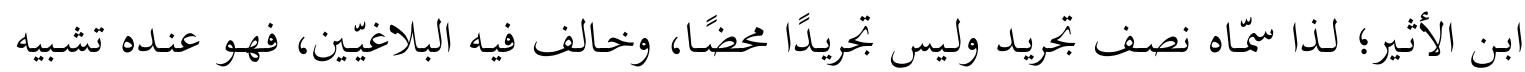

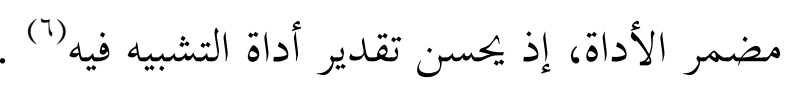

(1) أخرجه الصنعاني في مصنّفه

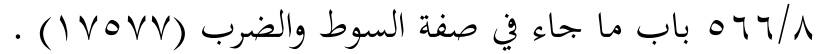
(ץ)

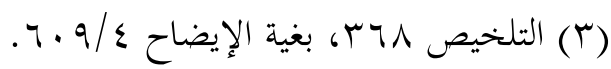

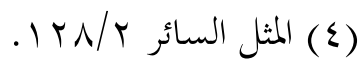

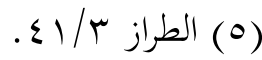

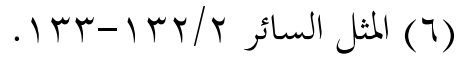




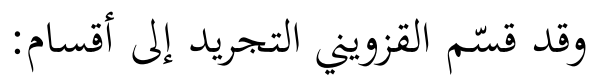

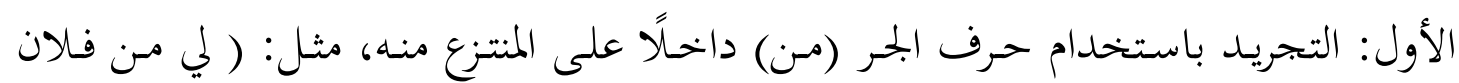

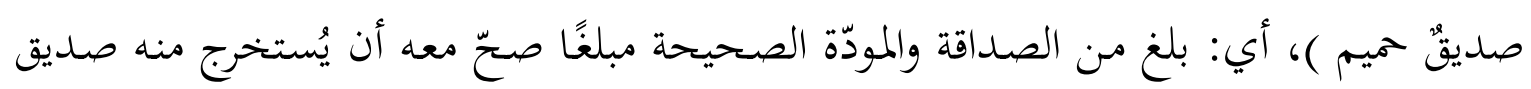
آخر مثله في صفاته، فهو منْبع أمثاله .

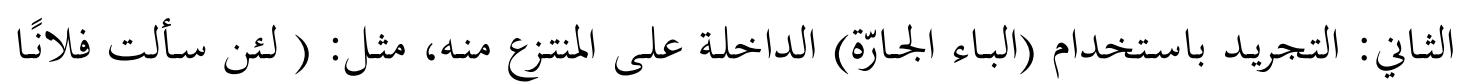

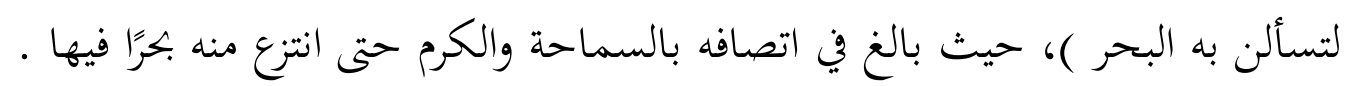

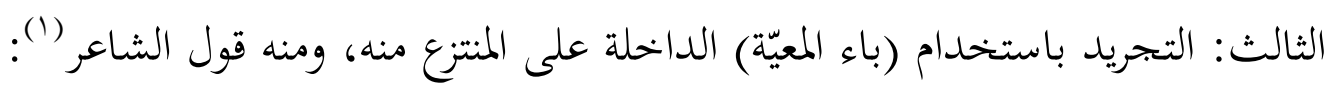

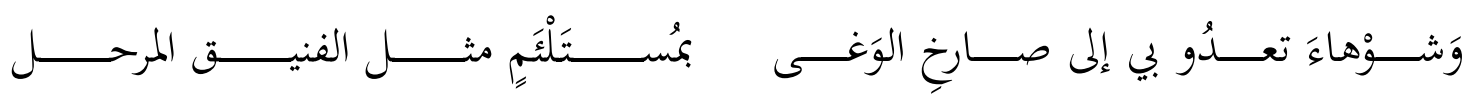
أي: ورُب فرس هذه صفتها تعدو بي لنجدة المستغيث في الحرب، ومعي مـن نفسي آخر مستعد للحرب، وقد بالغ في اتصافه بالاستعداد حتى انتزع وجرّد من نفسه مستعدًا آخر لابسًا درعًا .

الرابع: التجريد باستخدام حرف الجرّر (يف) الـداخل على المنتزع منه، مثل قول الله تعالى:

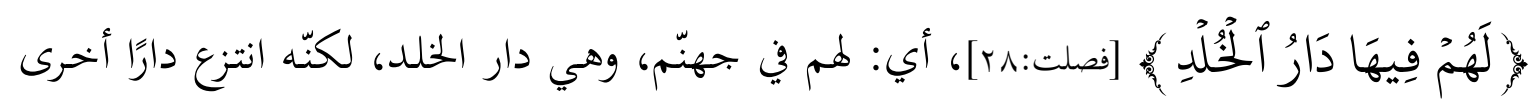

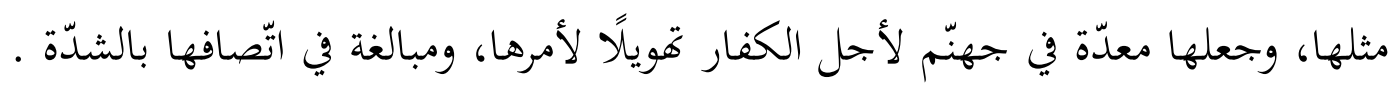

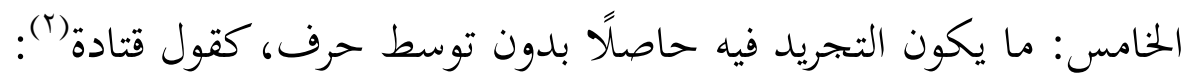

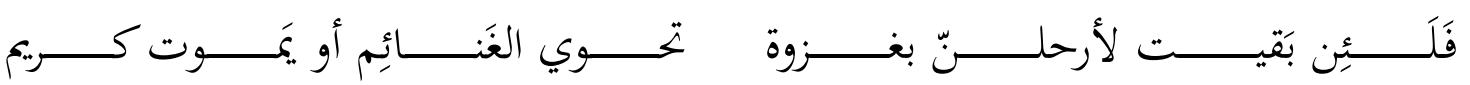
فالشاعر قد عنى بـ (الكريم) نفسه، فكأنّه انتزع وجرّد من نفسه كريمًا مبالغةً في كرمه .

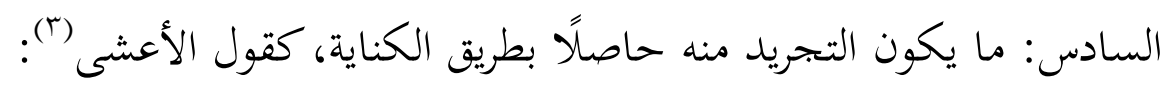

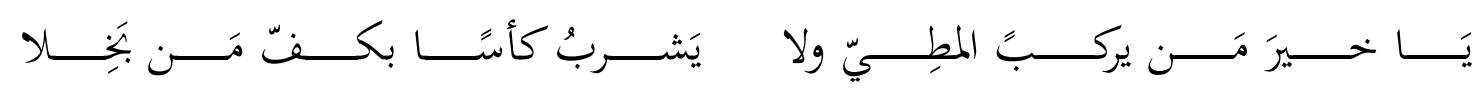


وهذا بتريد بطريق الكناية، حيث انتزع وجرّد من الممدوح جوادًا يشرب هو بكفّه على طريق الكناية، لأنّه إذا نفى عنه الشرب بكفّ البخيل، فقد أثبت له الشرب بكفِّ الكريم، ومعلومٌ أنّه

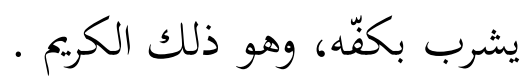

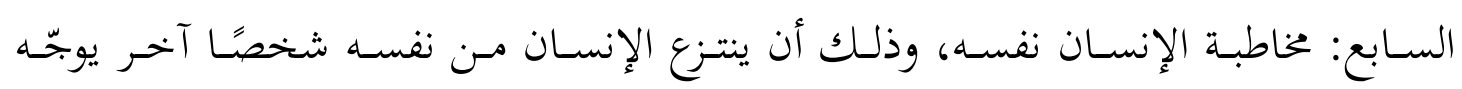
الخطاب إليه، كقول المتنبيّ (1):

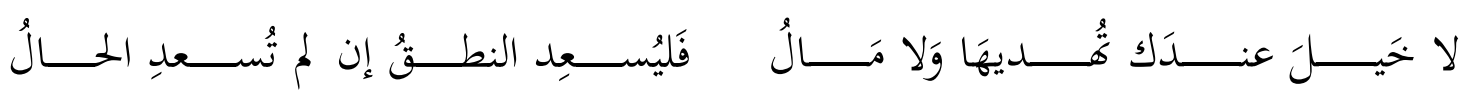
فالشاعر هنا ينتزع من نفسه إنسانًا آخر يخاطبه قائلاً: ليس عندك من الحيل والمال ما تمديه

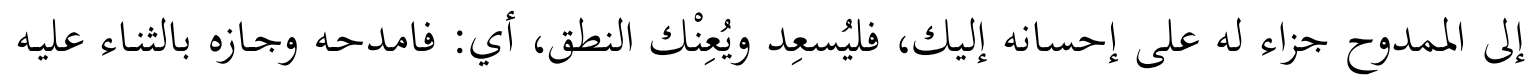
إن لم تعنك الحال على بحازاته بالمال أو الخيل (T) . 


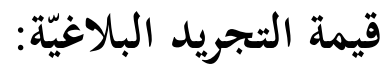

/ / المبالغـة وطلب التوسّع في الكـام؛ لأنّ ظـاهر التجريـد خطـابٌ للغير، وباطنه خطـابٌ

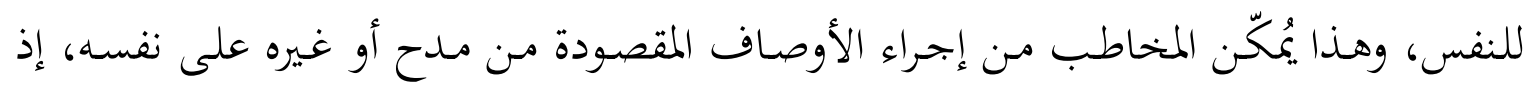

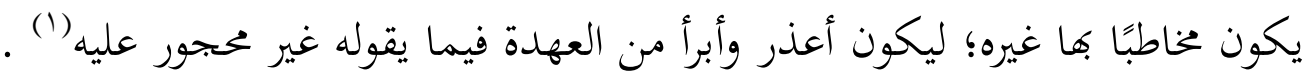

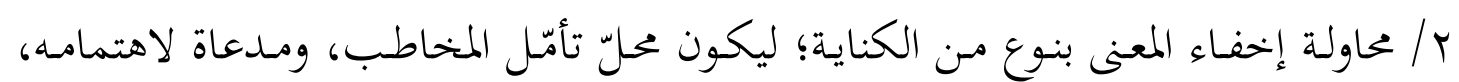
وذلك عندما يكون التجريد بغير الحروف .

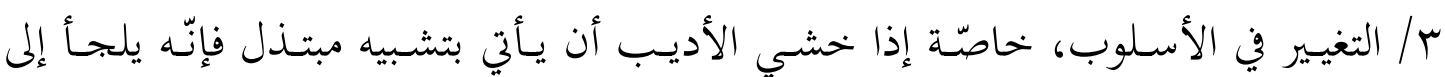

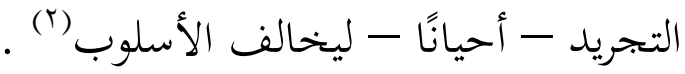




\section{علاقة التجريد بالقرآن الكريم:}

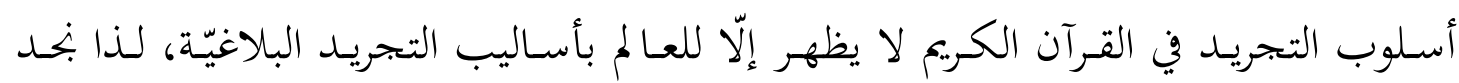

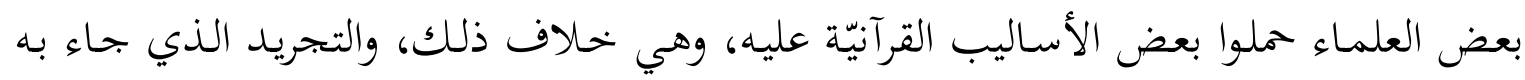

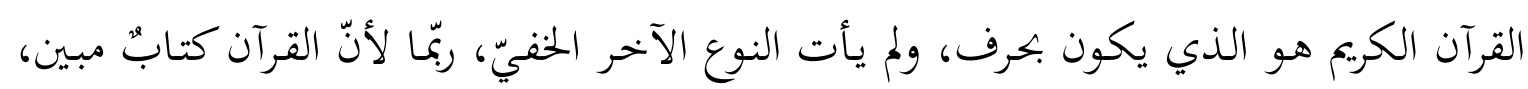

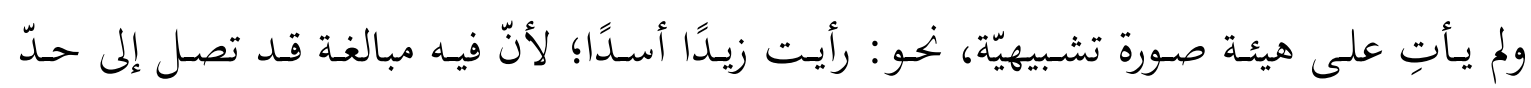

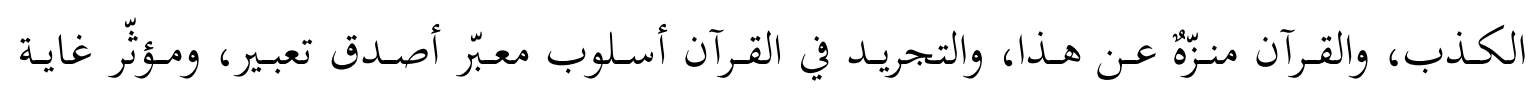

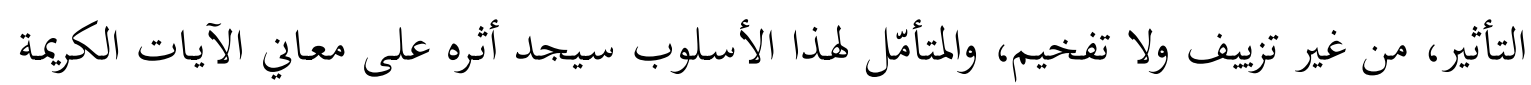

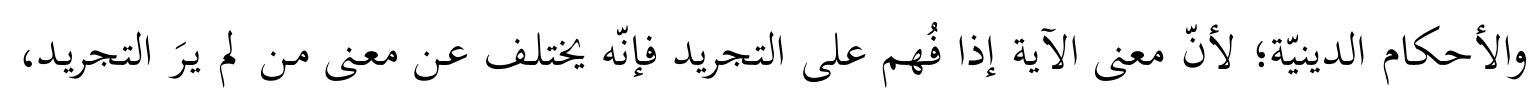
وينبني على كلا الفهمين حكم ديني (') . 
الدراسة التطبيقيّة للتجريد في القرآن الكريم

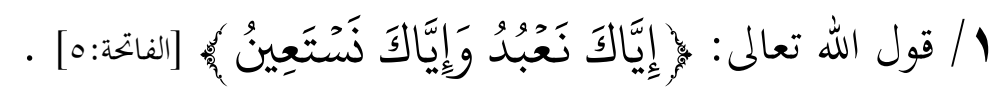

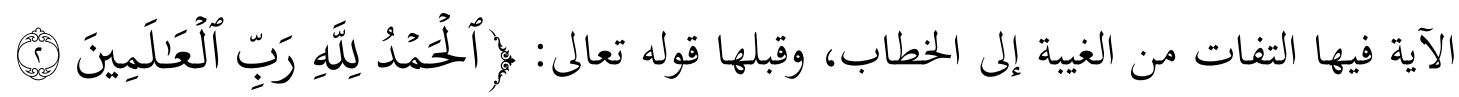

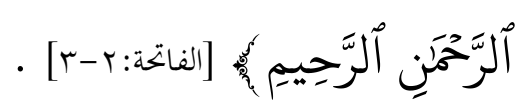

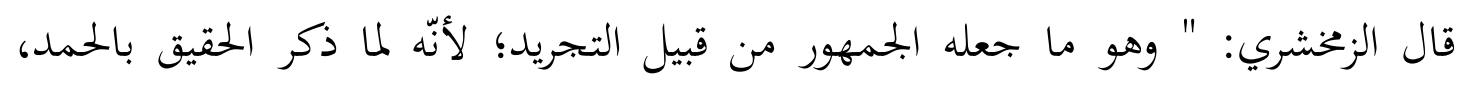

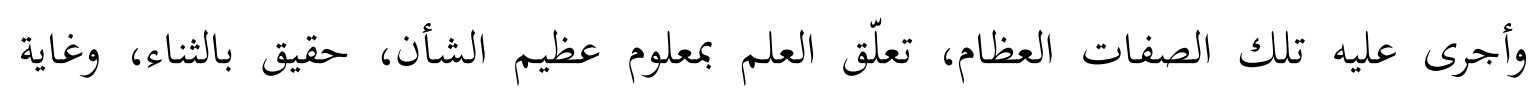

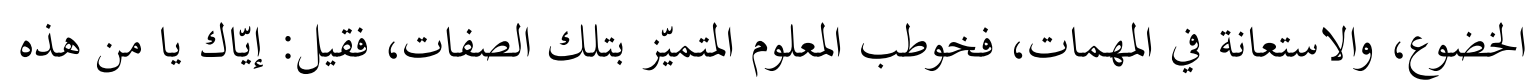

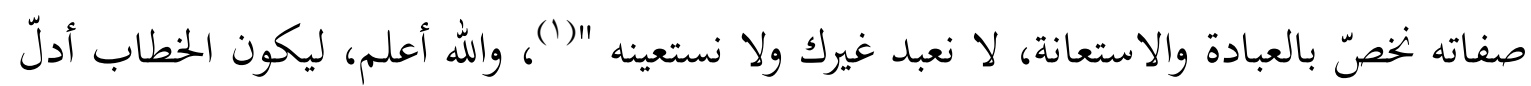

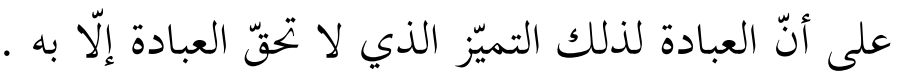

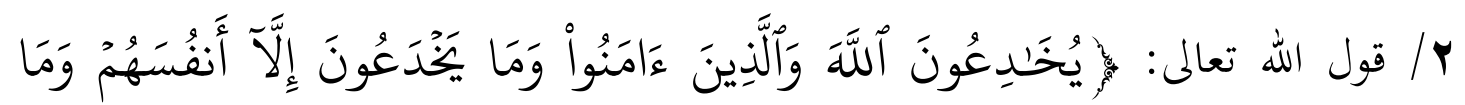

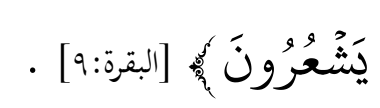

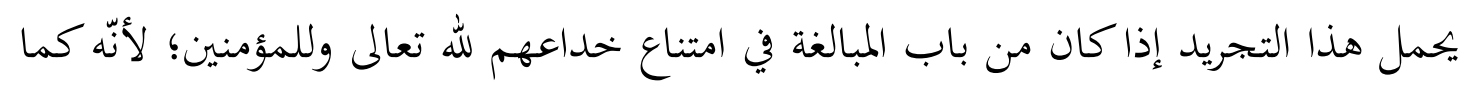

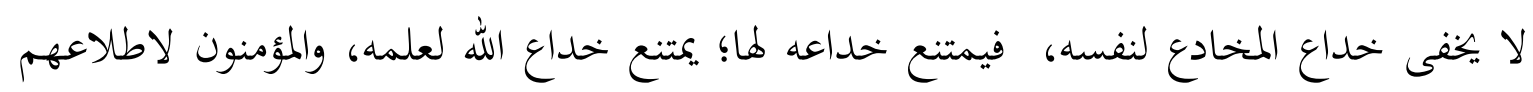

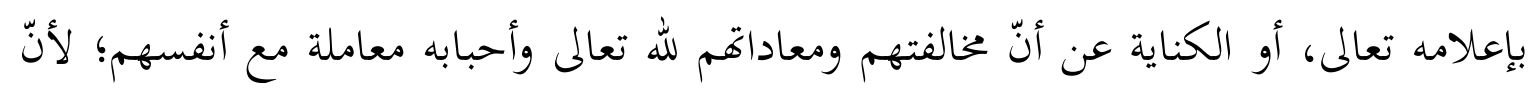

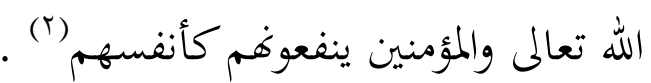




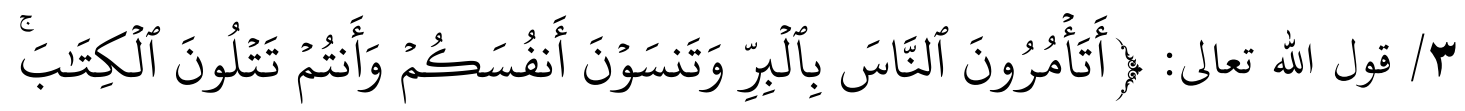

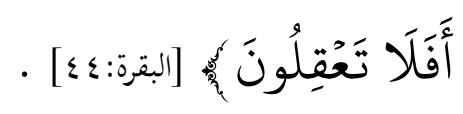

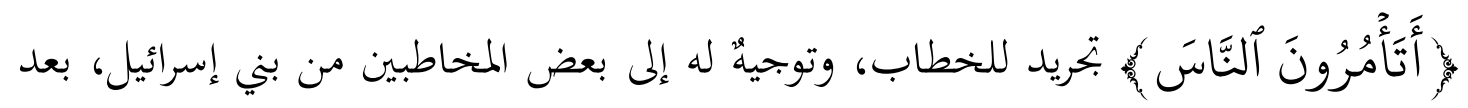

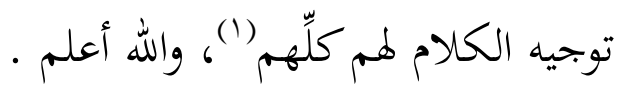

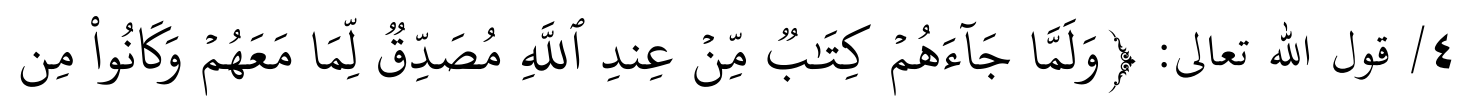

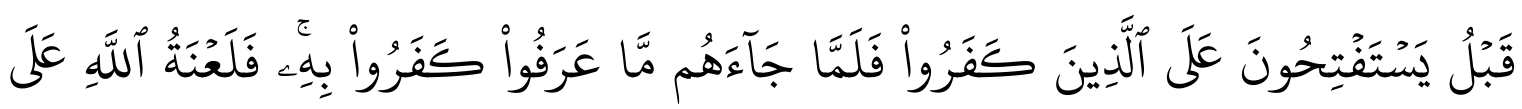

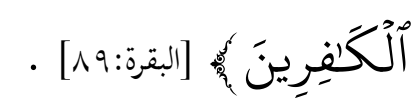

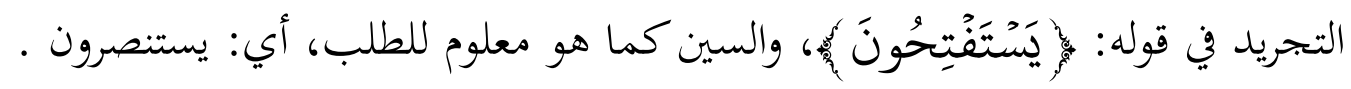

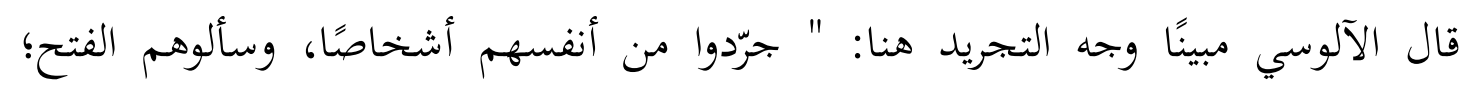
كقولم: استعجل، كأنه طلب العجلة من نفسه، ويؤول المعنى إلى يا نفس عرّيق المشركين أنّ نبيَّا

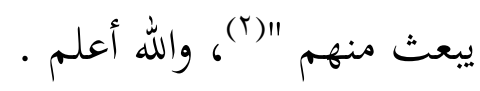

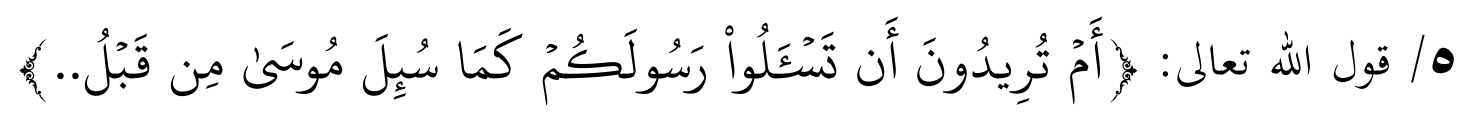

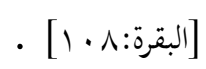

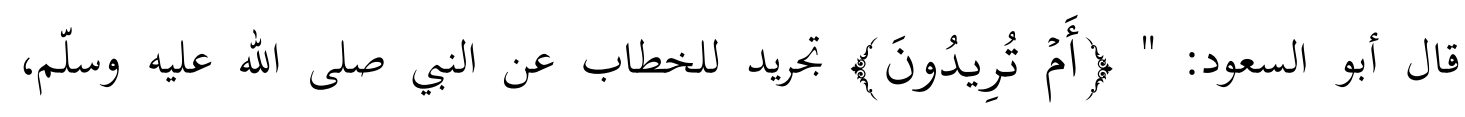

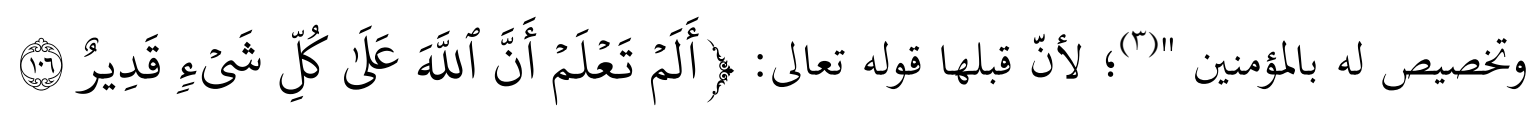

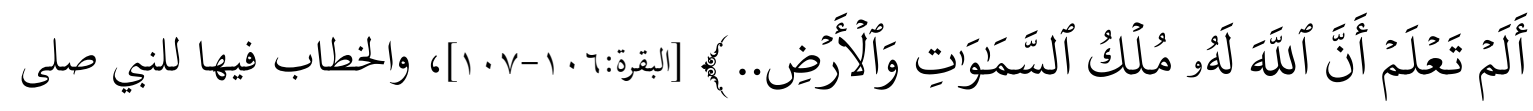

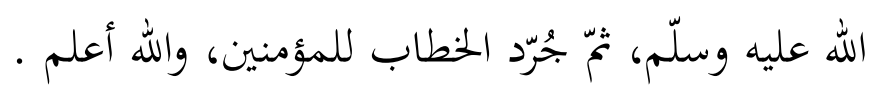

$$
\begin{aligned}
& \text { (1) إرشاد العقل السليم 9V/1. }
\end{aligned}
$$

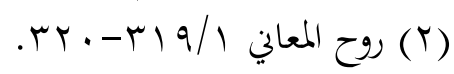

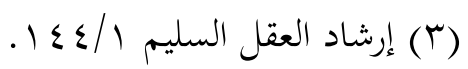




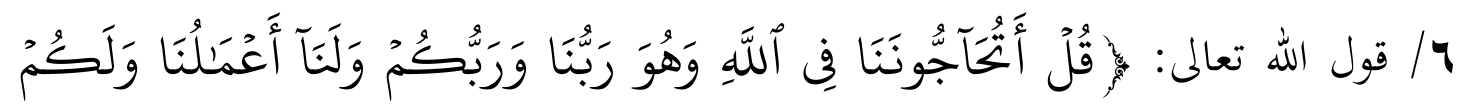

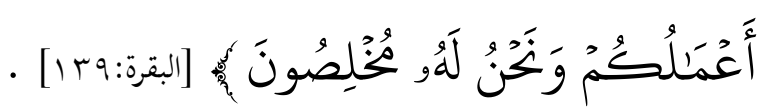
في الآية بتريد الخطاب للبي صلى الله عليه وسلّم بعد الخطاب للعام لامن قوله تعلى:

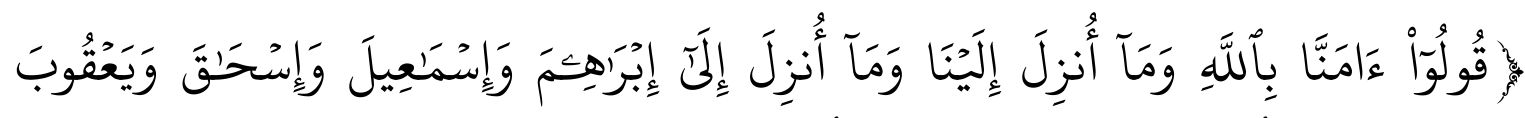

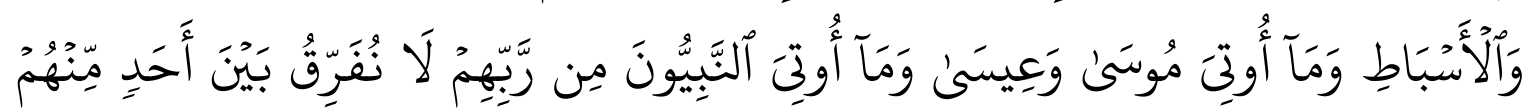

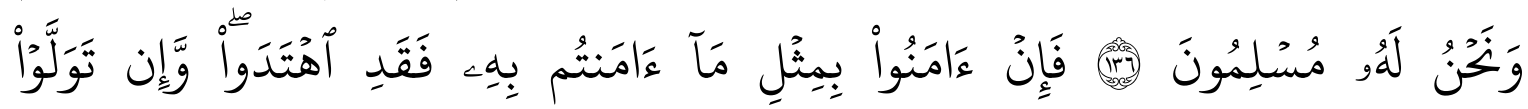

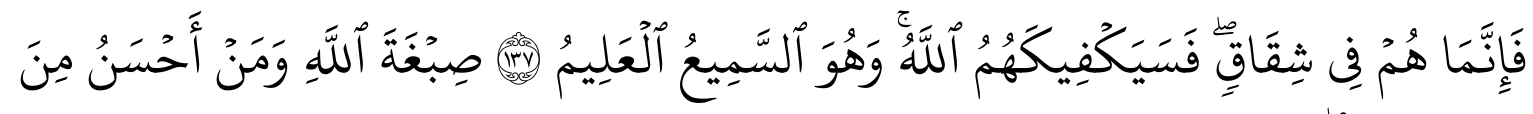

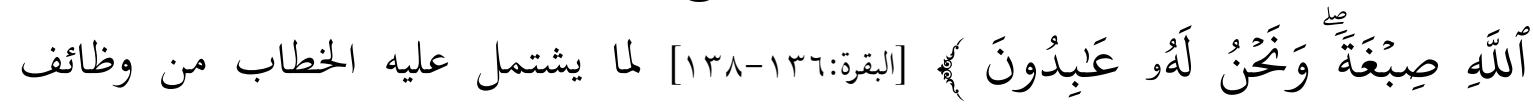

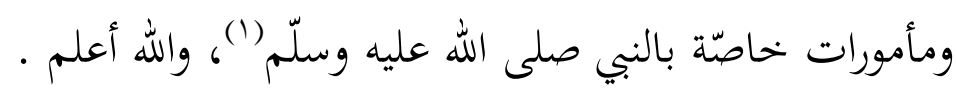

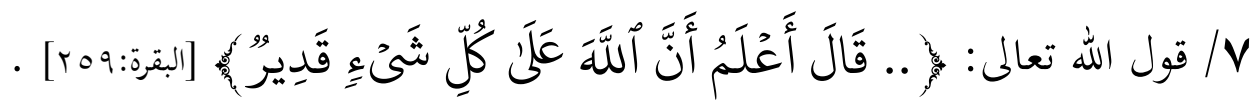

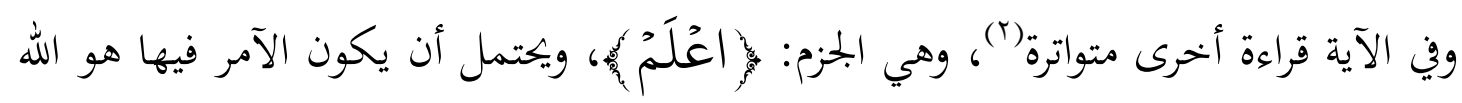

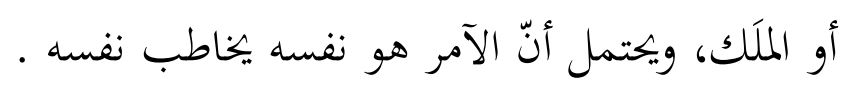
قال الآلوسي: " ويحتمل أن يكون المخاطب هو نفسه على سلى سبيل التجريد مبكتًا لها موبّنّا

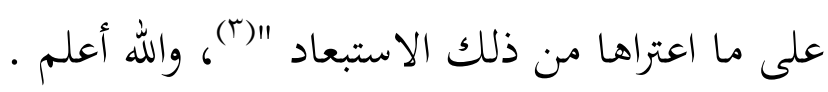

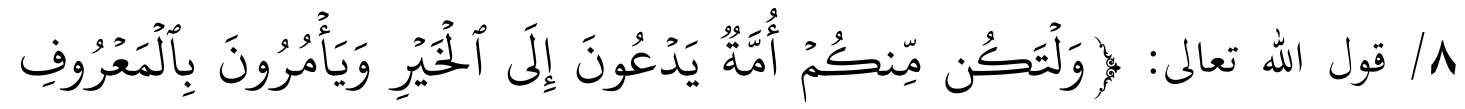

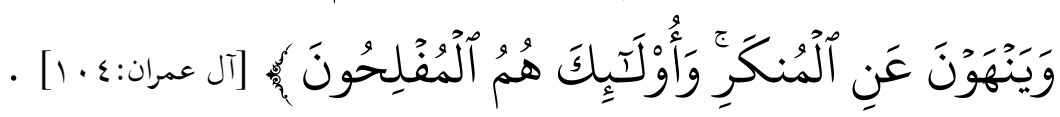

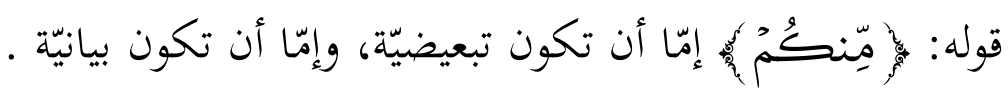

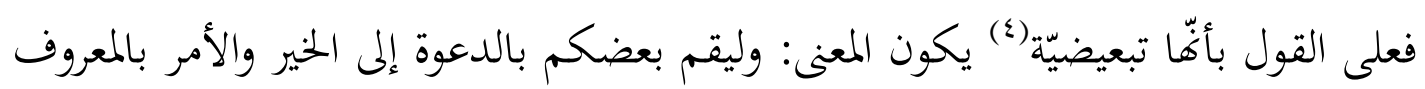


والنهي عن المنكر، وهو حينئذ من فروض الكفايات، وعلى القول الثاني يكون المعنى: ولتكونوا

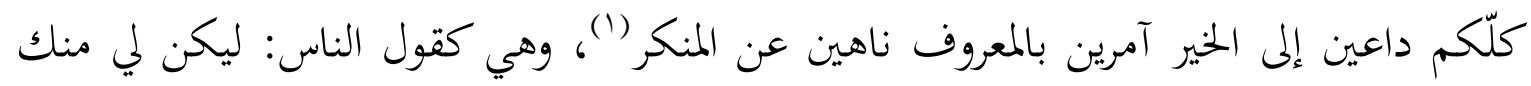

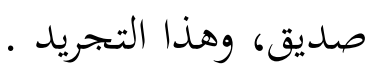

$$
\text { والذي يترجّح - والله أعلم - أَّا تبعيضيّة . ومديل }
$$

قال ابن عطيّة عن الدعوة إلى الله والأمر بالمعروف والنهي عن المنكر: " هذه الأفعال لا لا لإيه

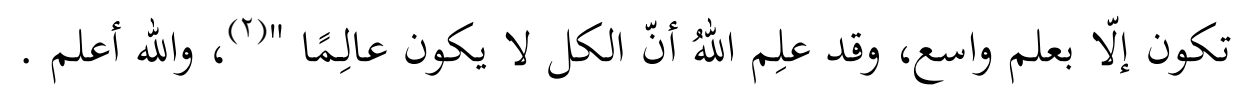

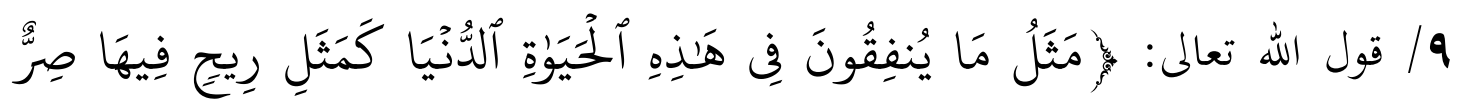

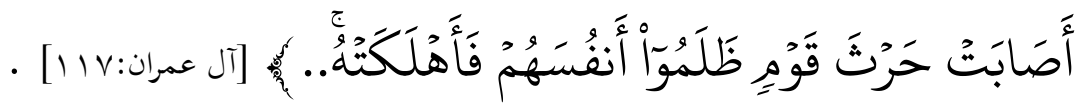

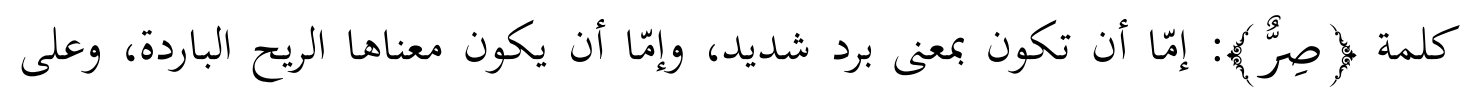

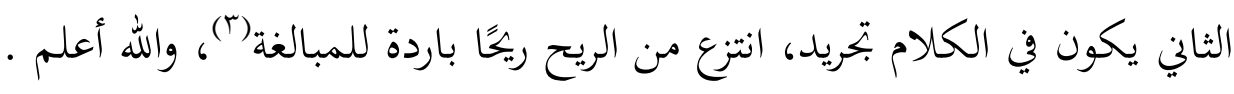

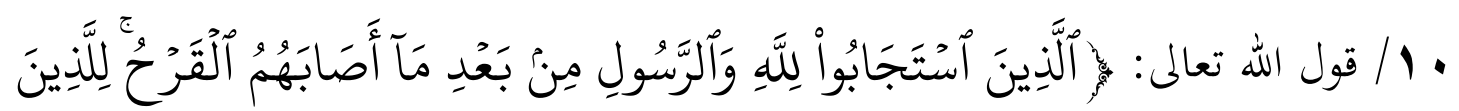

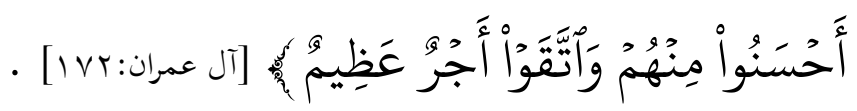

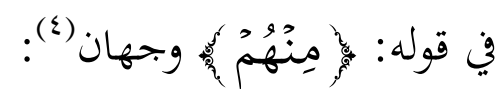

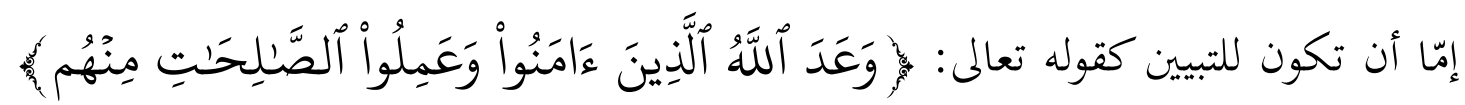

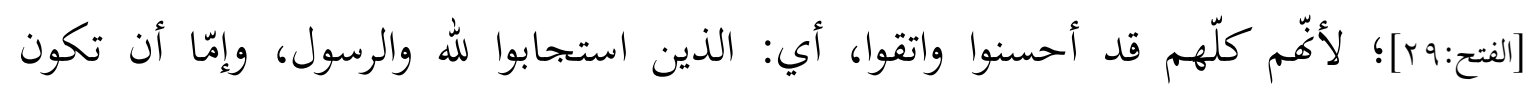
للتبعيض، والأول أقوى، والله أعلم .

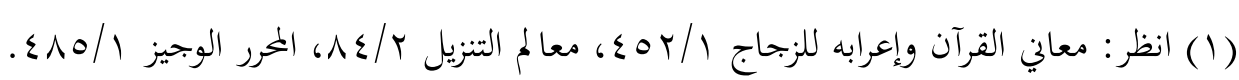

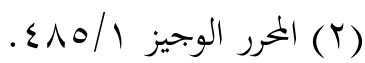

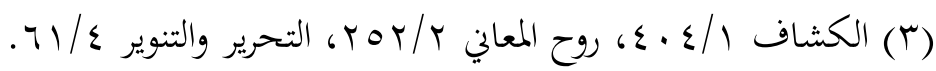

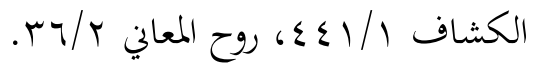




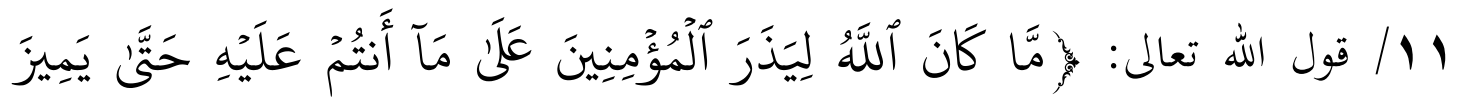

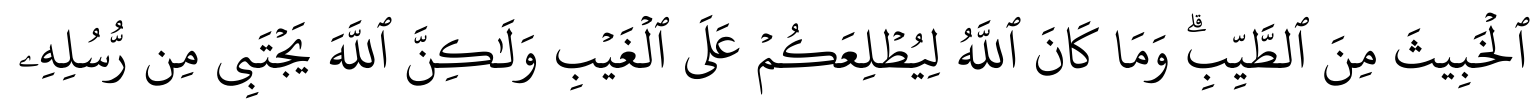

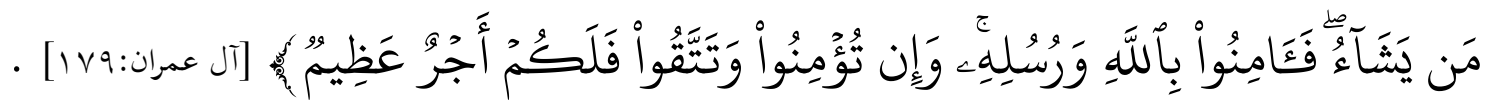

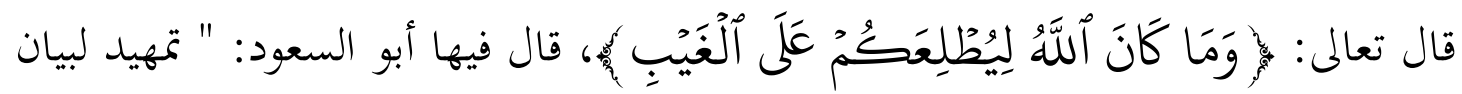

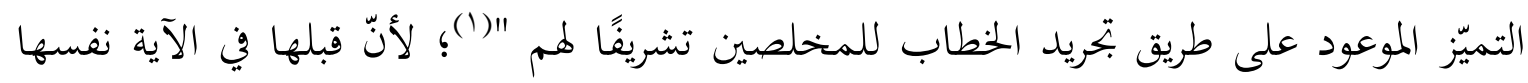

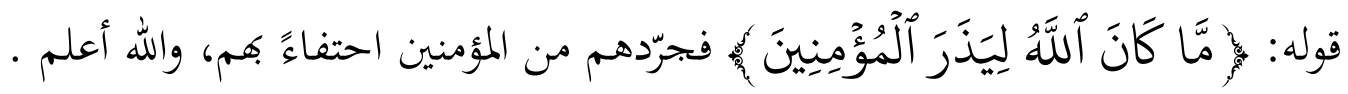

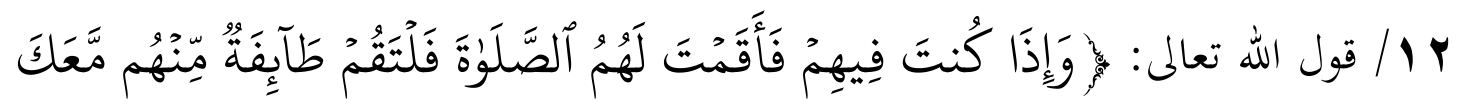

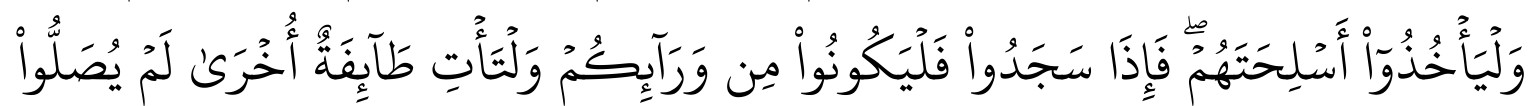

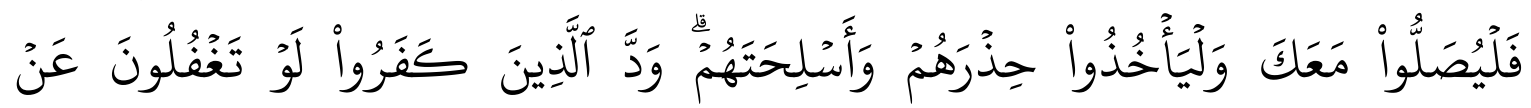

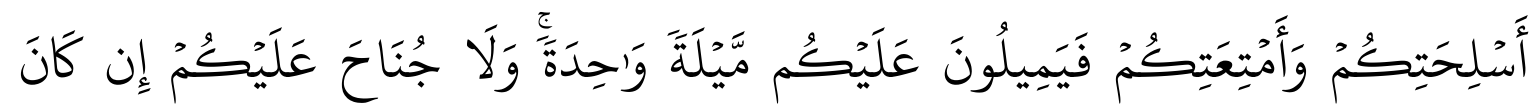

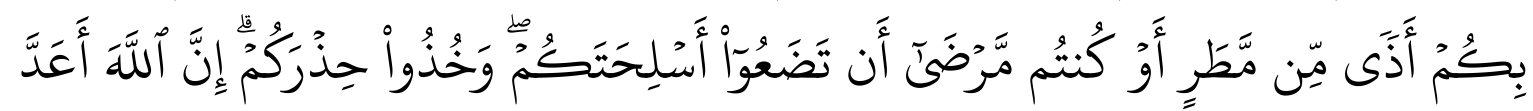

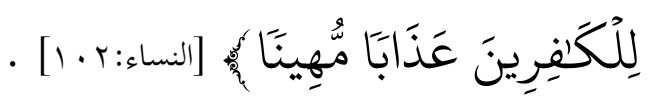

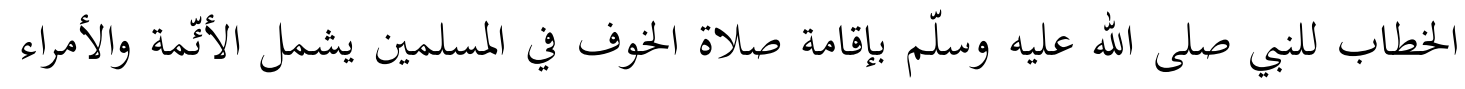
من بعده، ومن وقف عند ظاهر الخطاب خصصّ صلاة الخوف به عليه الصلاة والسلام، والأول

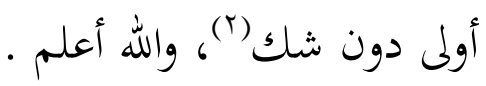




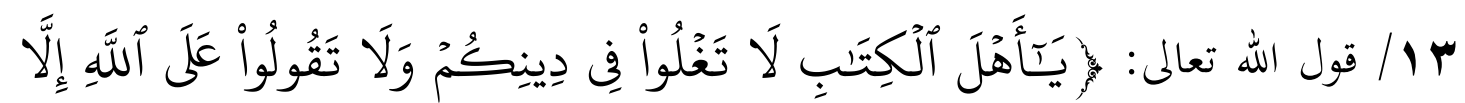

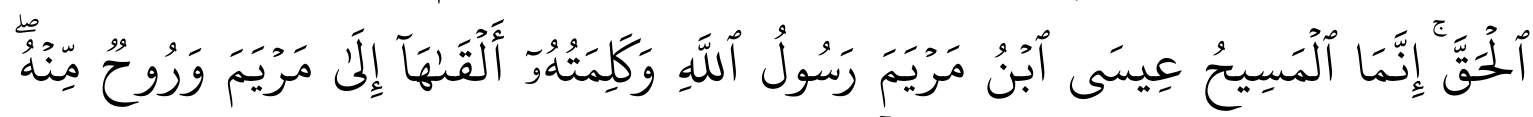

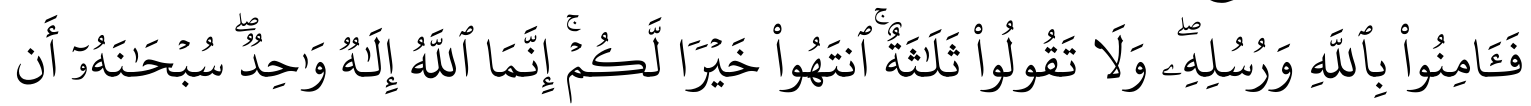

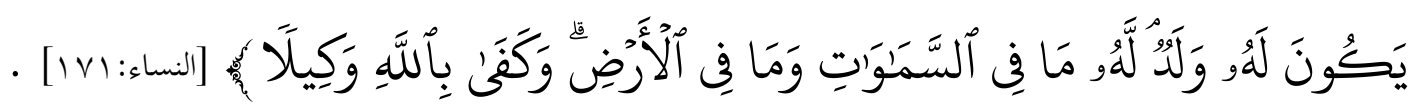

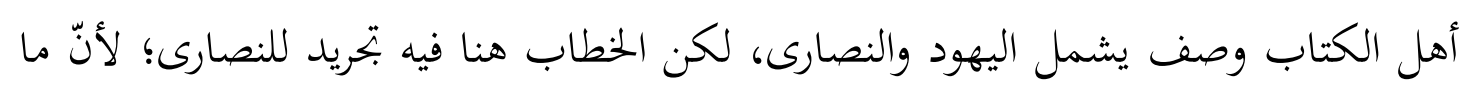
في الآية من عقيدة خاصة بالنبي عيسى عليه الصلاة والسلام .

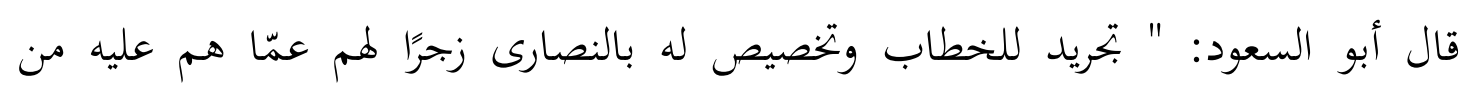

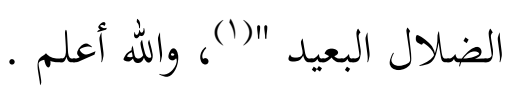

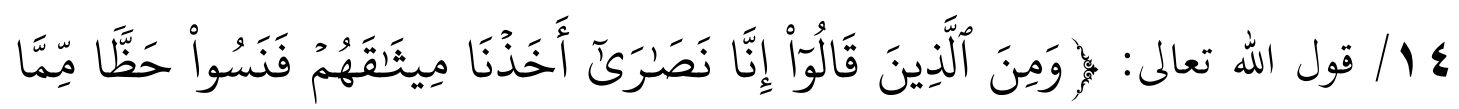

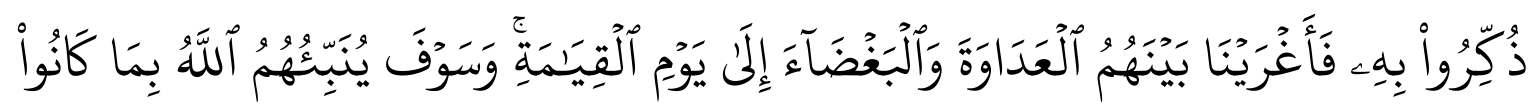

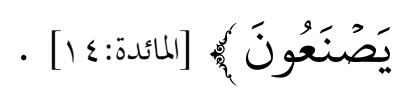

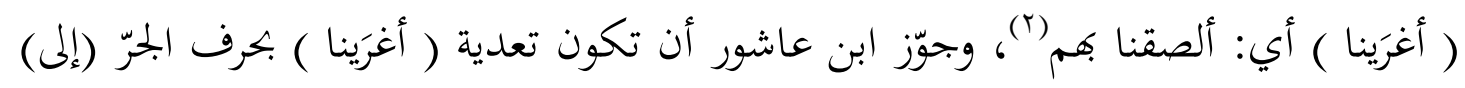

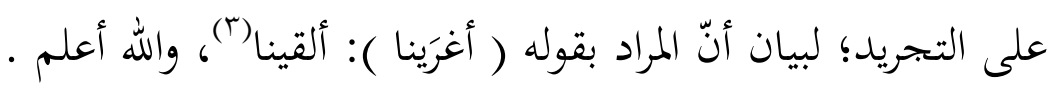

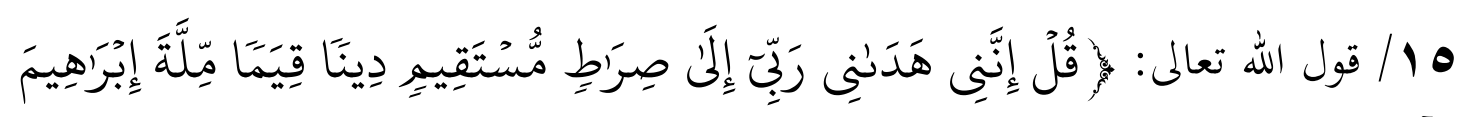

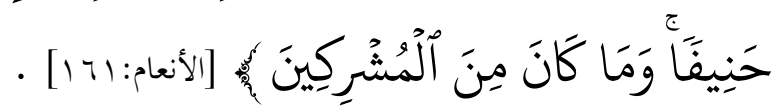

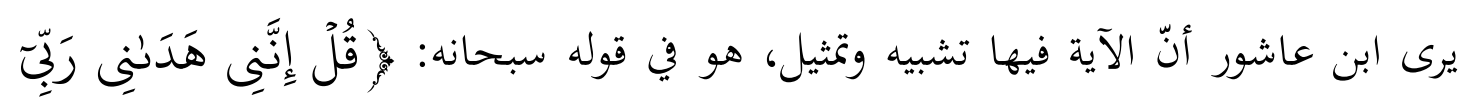

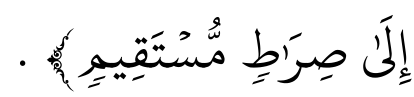
قال رمه الله: " شبّهت - أي: الآية - هيئة الإرشاد إلى الحقّ المبلّغ إلى النجاة بهيئة من

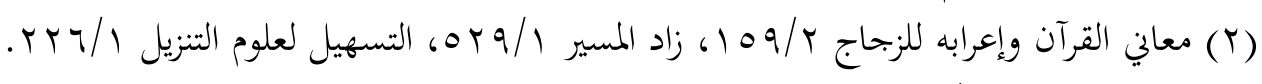

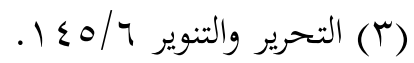


يدلّ السائر على الطريق المبلّغة للمقصود "((1)، ومن هنا كان في رأيه أن يكون قوله: (بِدينًا ) تحريدًا للاستعارة مؤذنًا بالمشبَّه، وربما كان الأولى أن يكون الكلام على أصله لا تشبيه فيه ولا

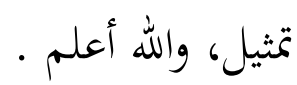

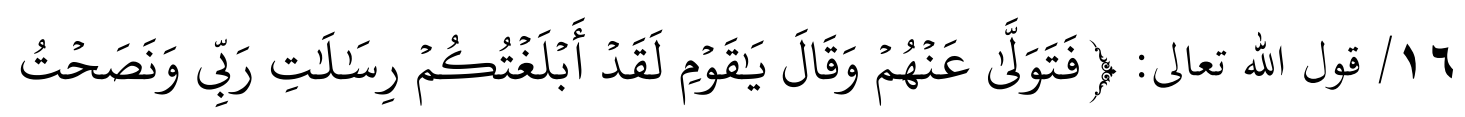

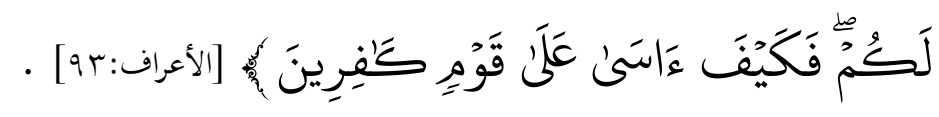

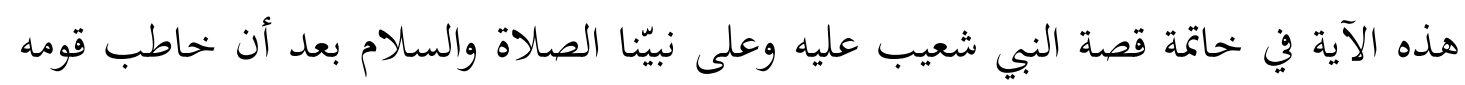

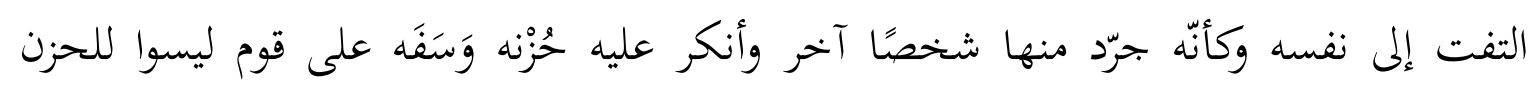

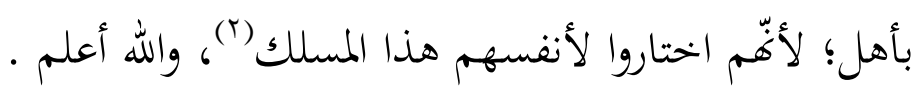

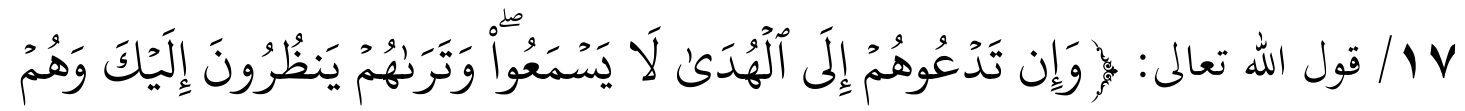

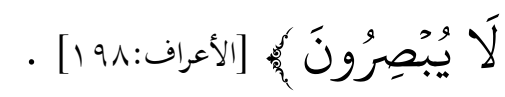

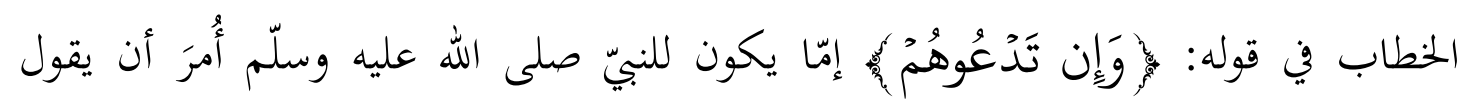

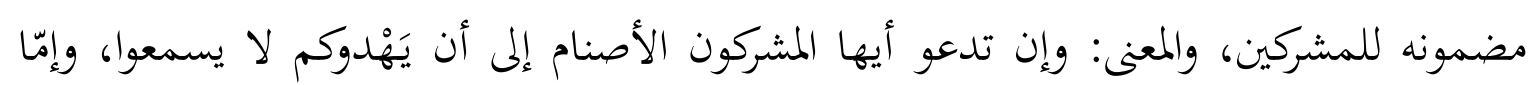

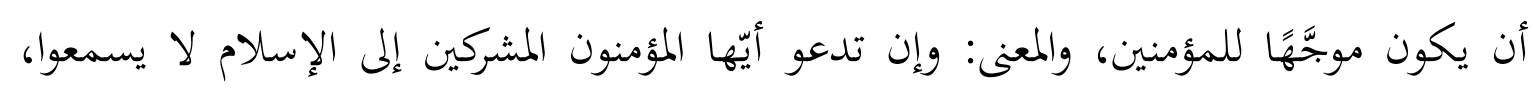

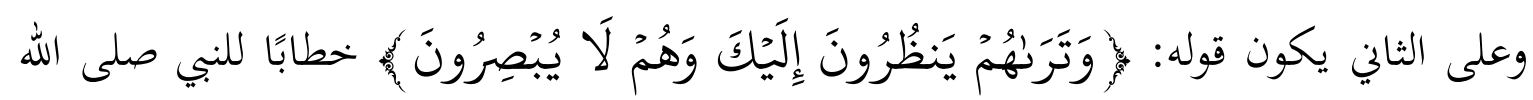

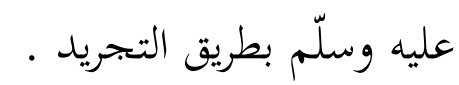
قال أبو السعود: " ثيّ خوطب صلى بطئ الله عليه وسلم بطريق التجريدِ بأنك تراهم ينظرون إليك

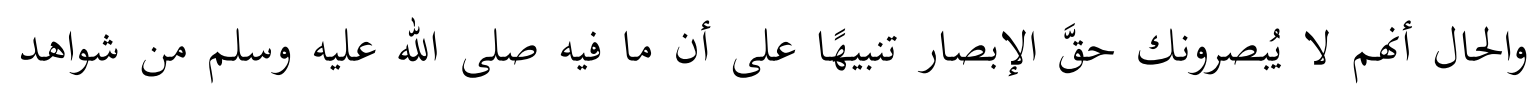

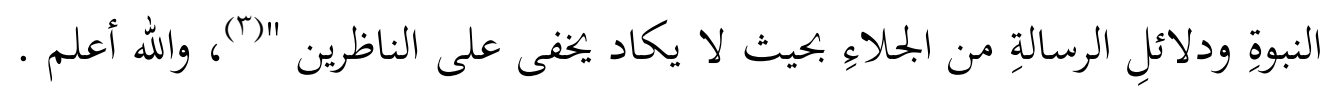




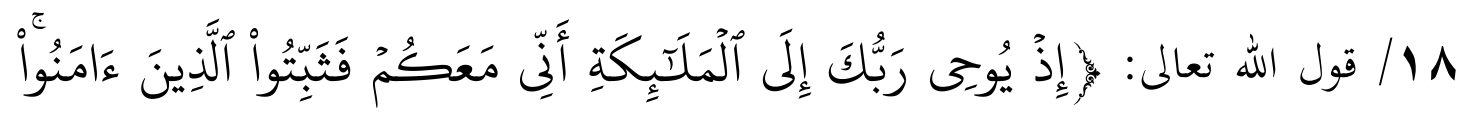

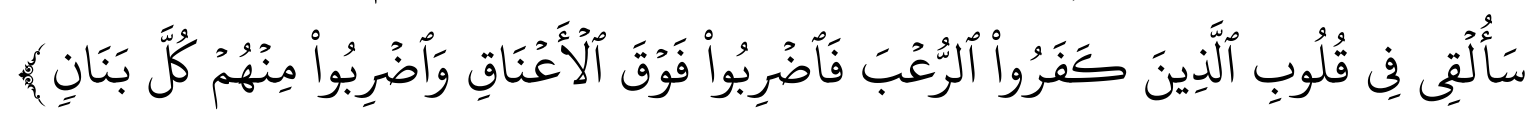
- [الأنفال:1r]

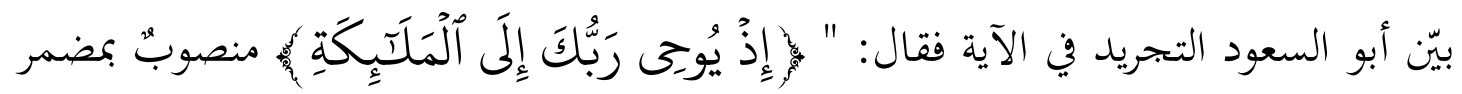
مستأنفٍ خوطب به النبيٌّ صلَّى الله عليه وسلم بطريق التجريدِ حسبما تنطِق به الكافُ لِِما أن المأمورَ به مما لا يستطيعه غيره صلى الله عليه وسلم فإن الوحيَ المذكورَ قبل ظهورٍِ بالوحي المتلوِّ

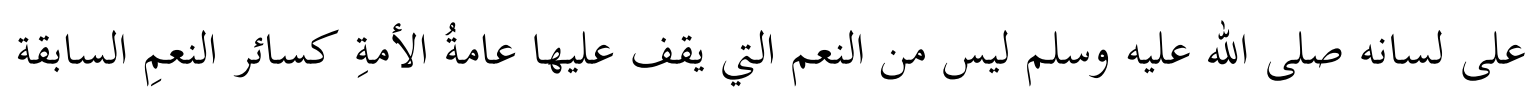

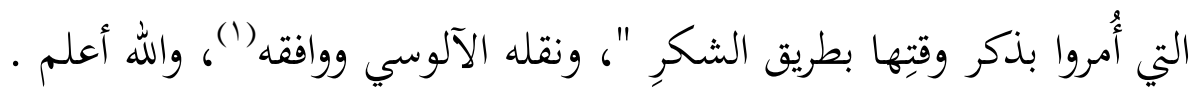

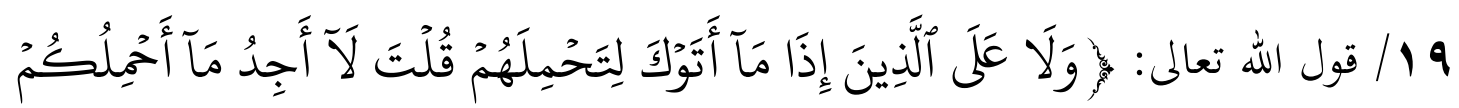

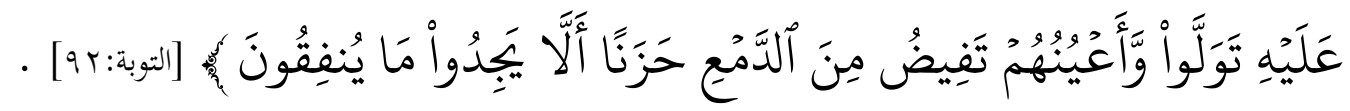

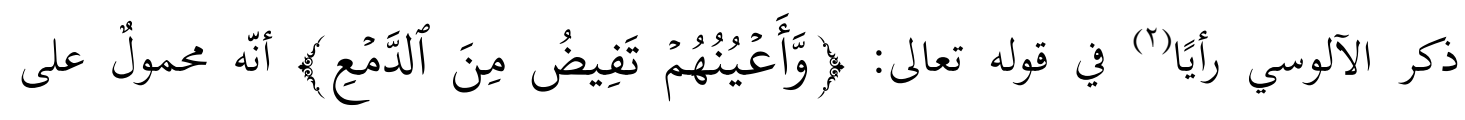

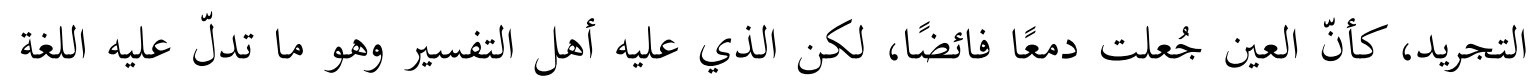

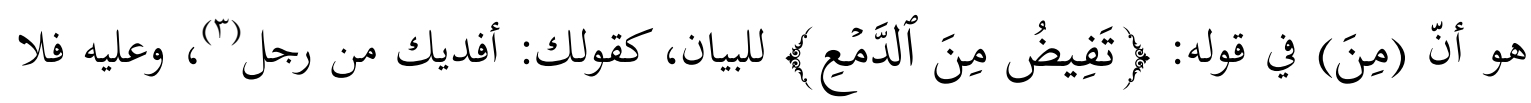
يتوجه القول بالتجريد هنا، والله أعلم . 


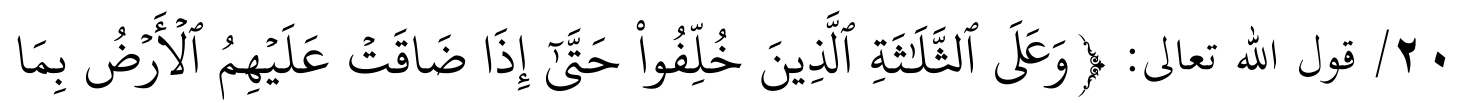

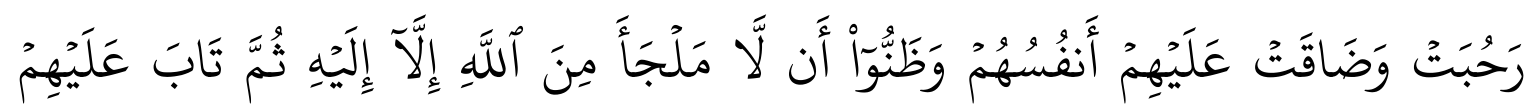

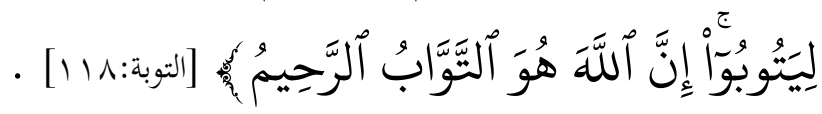

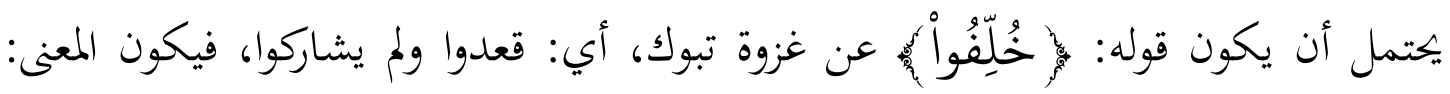

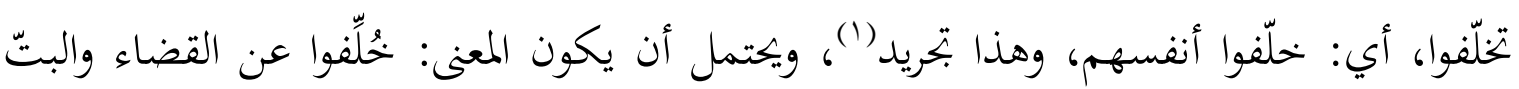

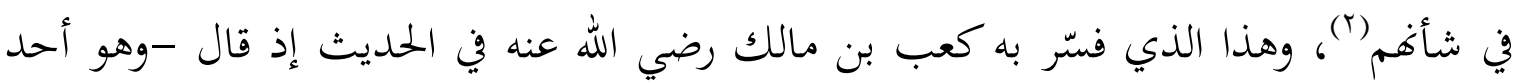

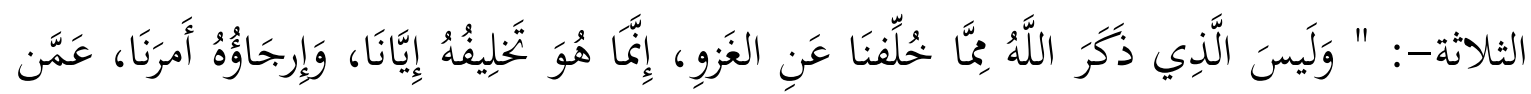

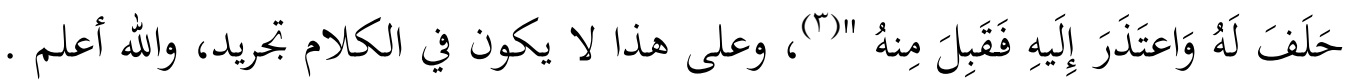

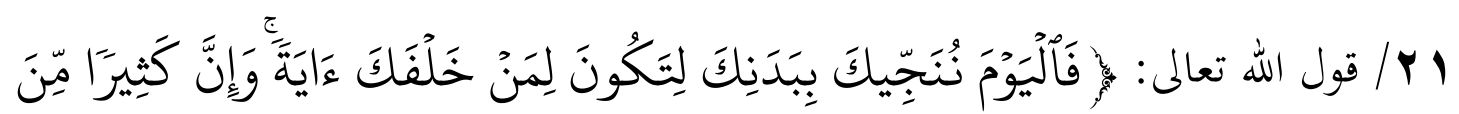

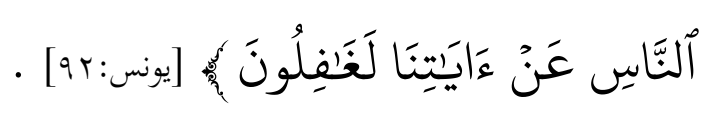

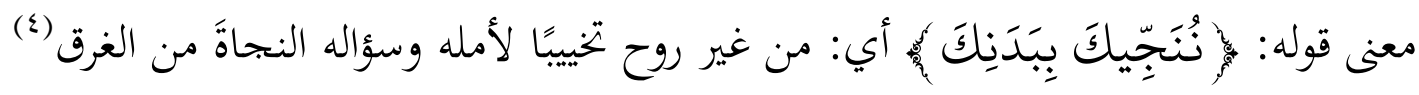
وذكر الآلوسي أنهّ قد حملها بعضهم(0) على التجريد، والمعنى: ننجّي بدنك، والباء زائدة،

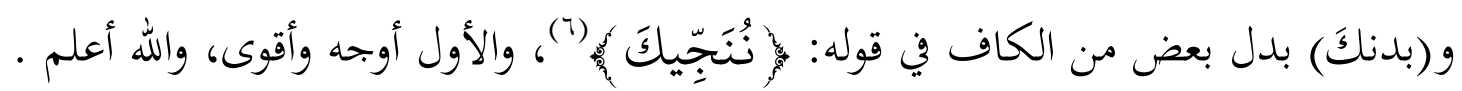

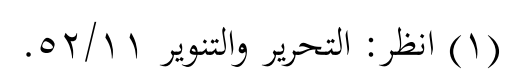

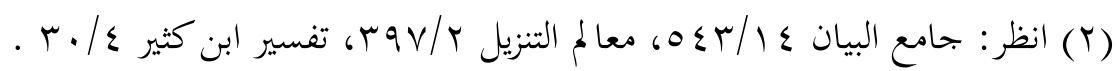

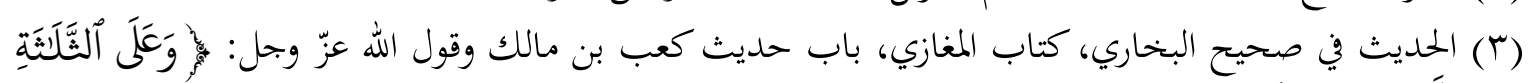

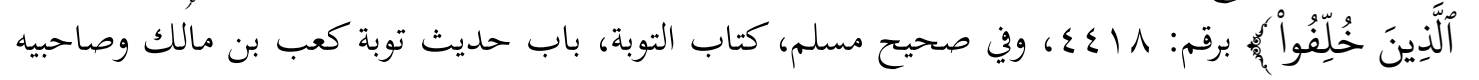

$$
\begin{aligned}
& \text { برقم: TV79 }
\end{aligned}
$$

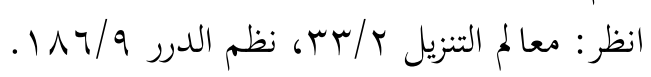

$$
\begin{aligned}
& \text { (1) لم يسمّه الآلوسي. }
\end{aligned}
$$

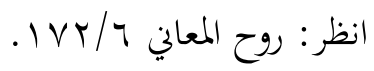




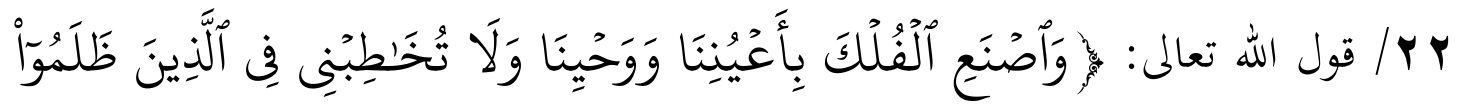

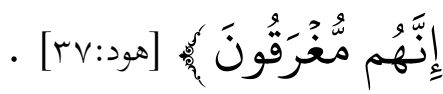

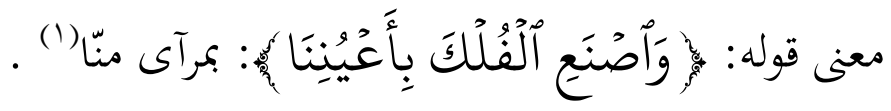

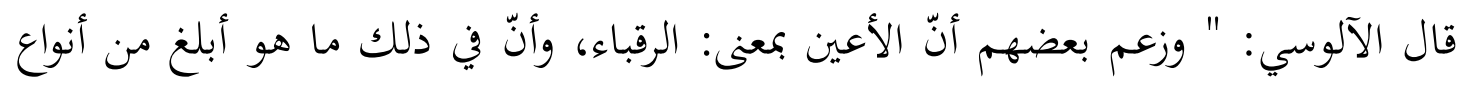

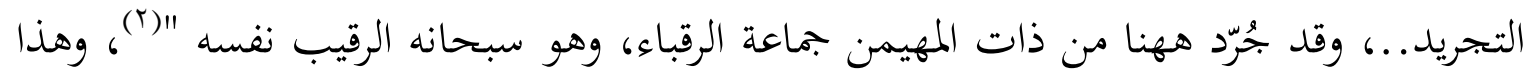

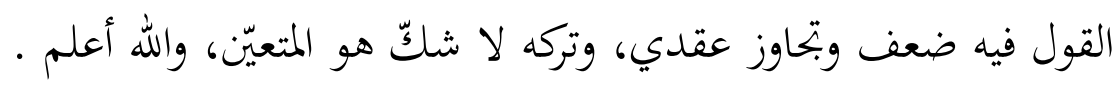

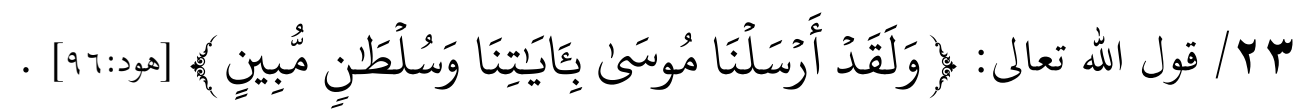

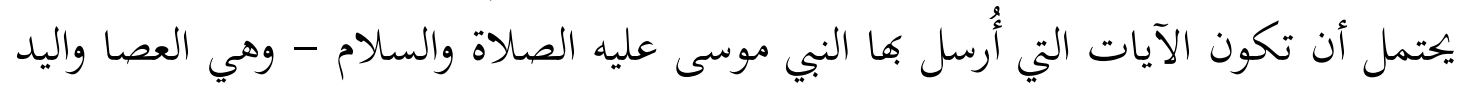

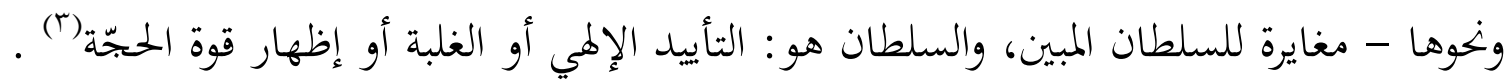

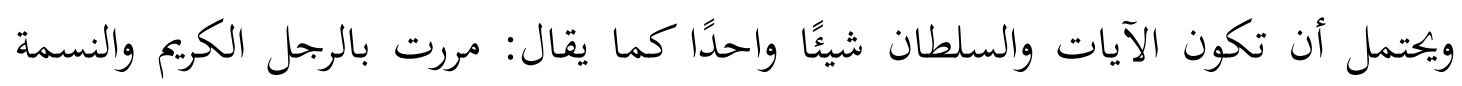

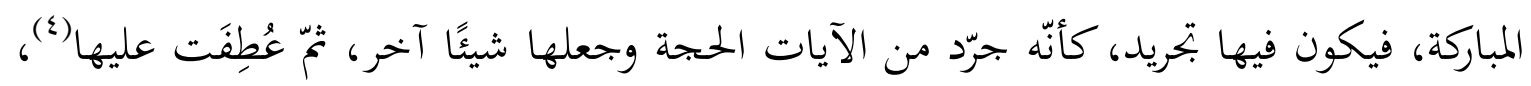

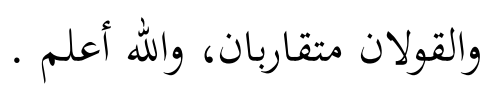

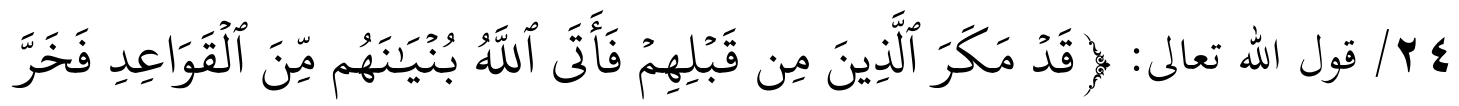

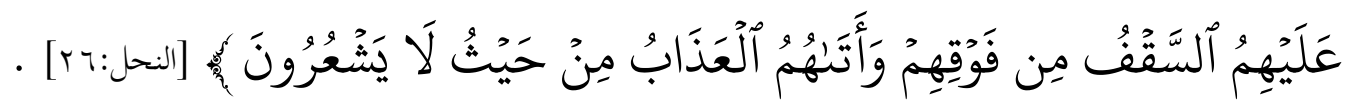

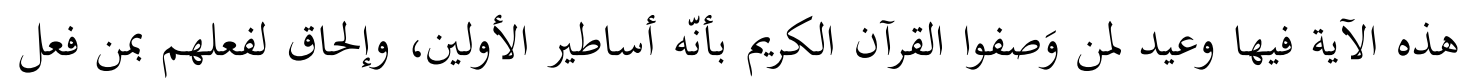

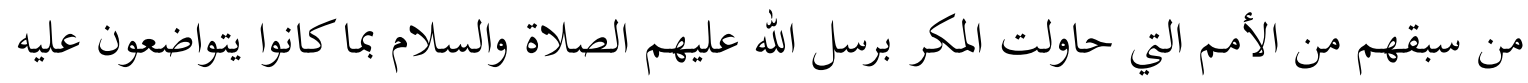

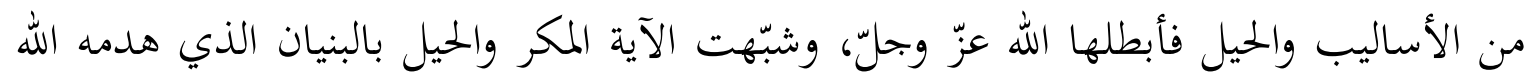
عليهم (0)

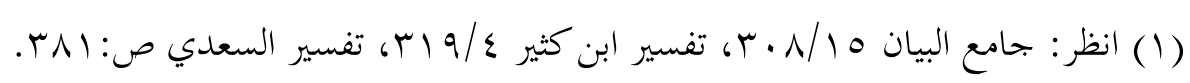

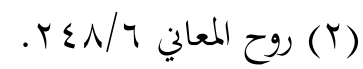

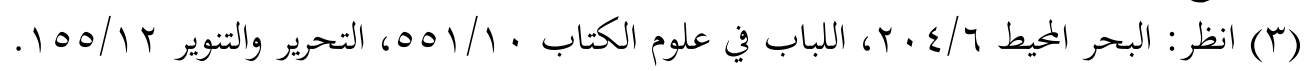

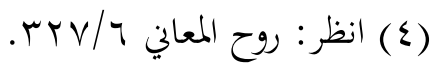

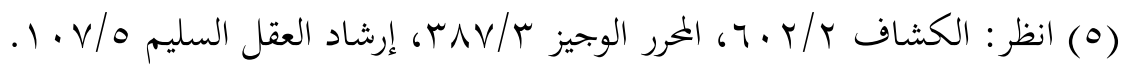


ولهذا قال الآلوسي عن أسلوب الكلام في الآية: " وجُجوزّز أن يرتكب فيه التجريد، أي: سوّوا

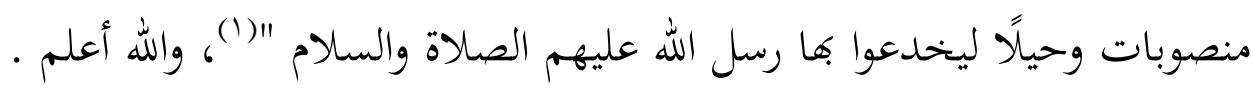

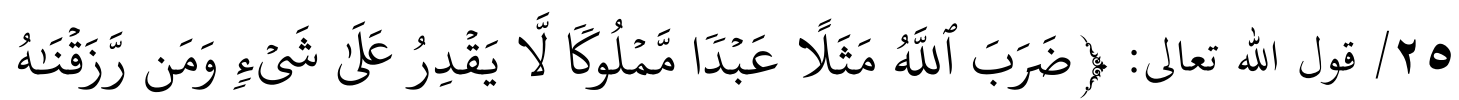

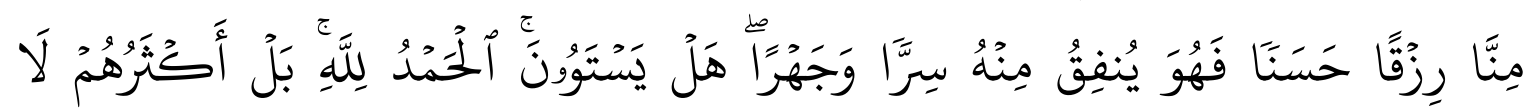

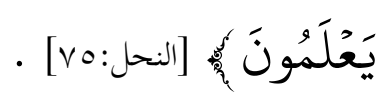

هذا مثل ضربه الله تعالى يُوضِّحُ تباين الحال بينه عزّ وجلّ وبين ما أشركوا، والمثل المضروب

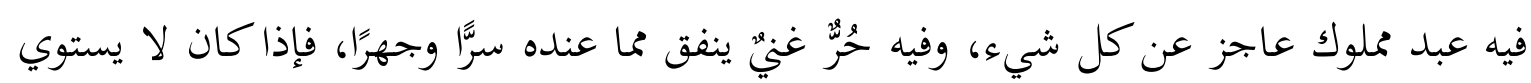

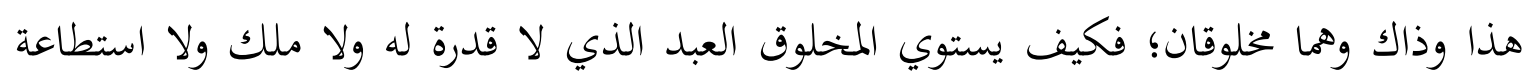

$$
\begin{aligned}
& \text { بالله الخالق المالك كل شيء؟!(؟) . }
\end{aligned}
$$

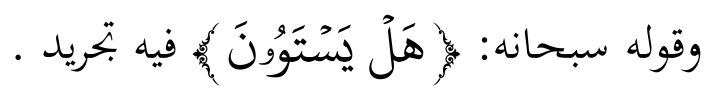

قال ابن عاشور: فصيغة الجمع هنا بتريد للتمثيلية، أي: هل يستوي أولئك مع الإله الحق

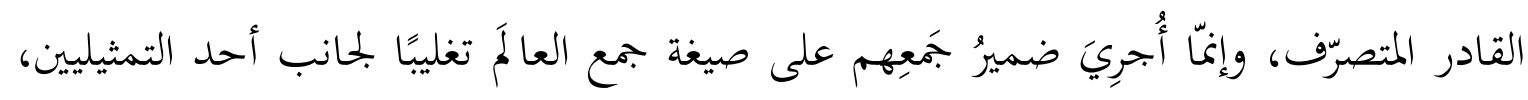

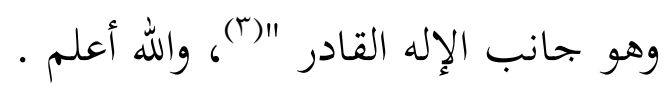

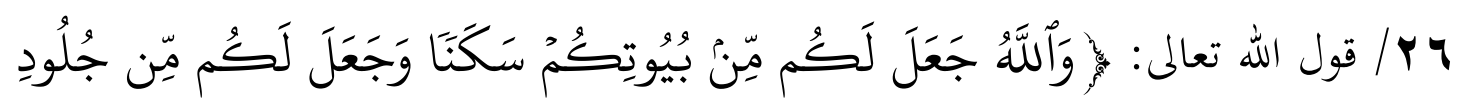

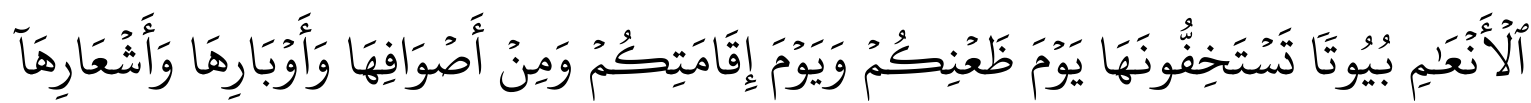

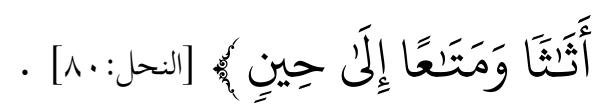
هذه الآية تشير إلى نعمة من الله ألهم بها عباده، وهي اتخاذ المساكن .

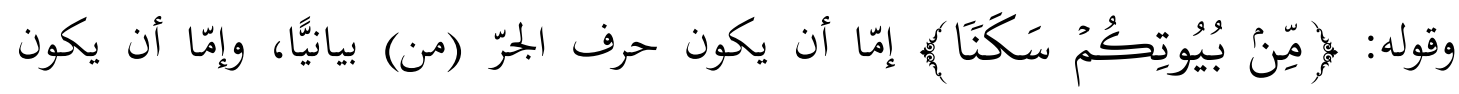
ابتدائيًا، وعلى الثاني يكون في الكلام بتريد . 
قال ابن عاشور: " ويكون الكالام من قبيل التجريد بتنزيل البيوت منزلة شيء آخر غير

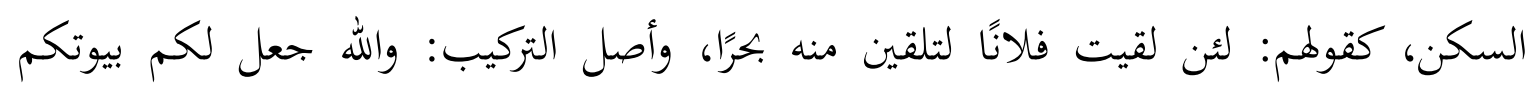

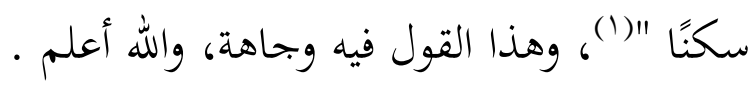

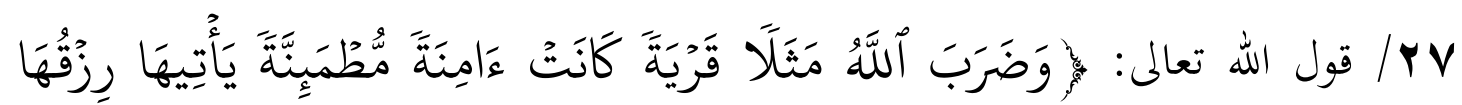

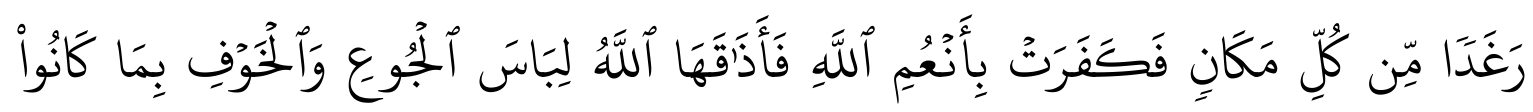

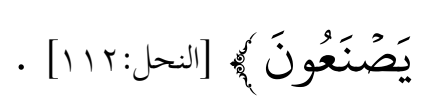

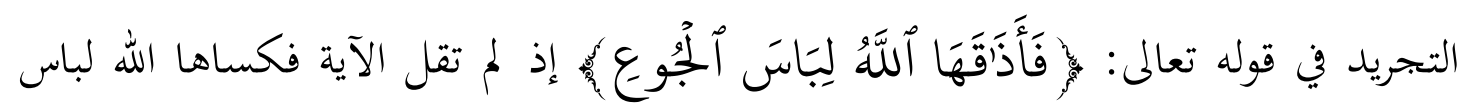

$$
\text { الجوع أو فأذاقها طعم الجموع، وبيان ذلك أنّ هذا من بتريد الاستعارة . }
$$

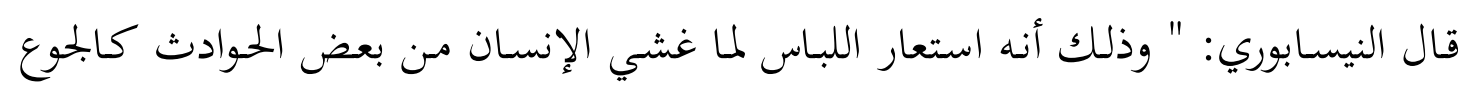
والخوف لاشتماله عليه اشتمال اللباس على اللابس، ثم ذكر الوصف ملائما للمستعار له وهو

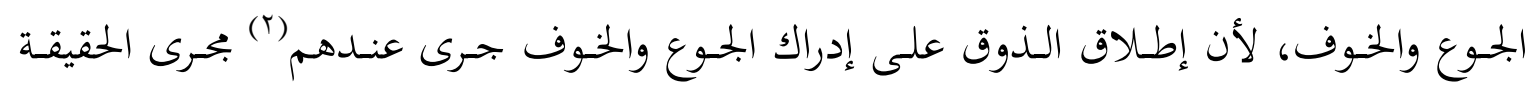
فيقولون: ذاق فلان البؤس والضر وأذاقه غيره. فكانت الاستعارة بحردة "(())، والله أعلم .

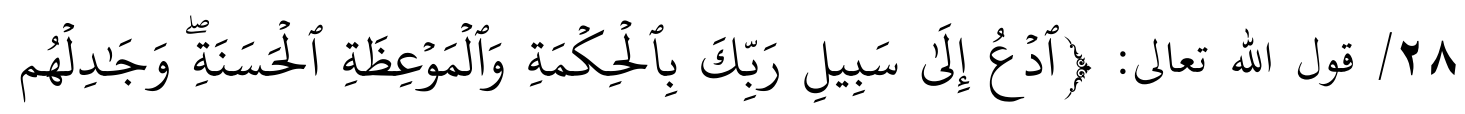

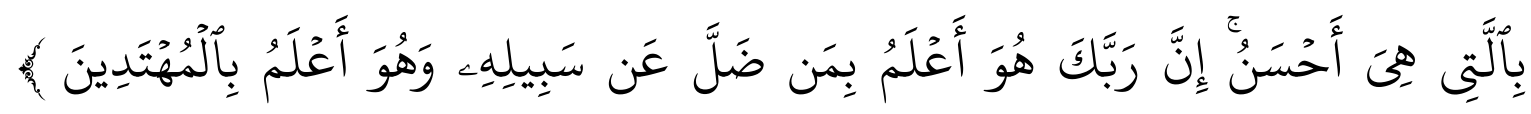

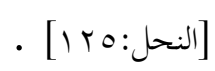

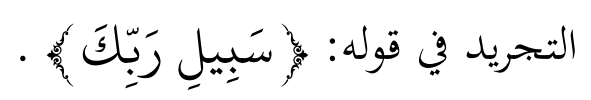

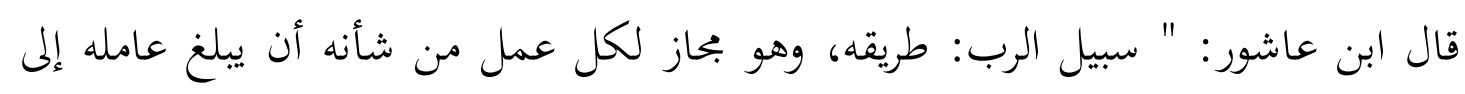

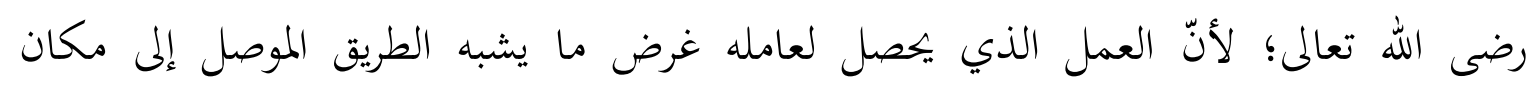
مقصود، فلذلك يستعار اسم السبيل لسبب الشيء "، ثمّ قال مصرّحًا بالتجريد: " وإضافة سبيل

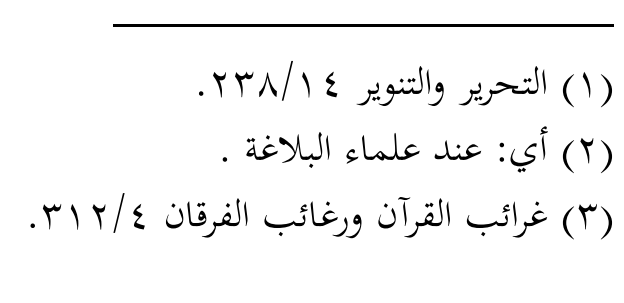


إلى ربك باعتبار أن الله أرشد إليه وأمر بالتزامه. وهذه الإضافة تجريد للاستعارة. وصار هذا

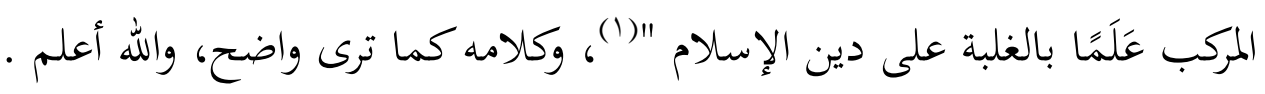

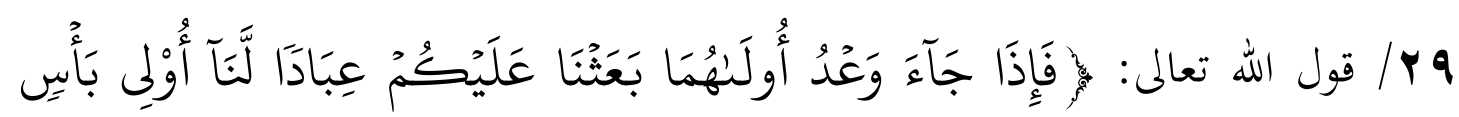

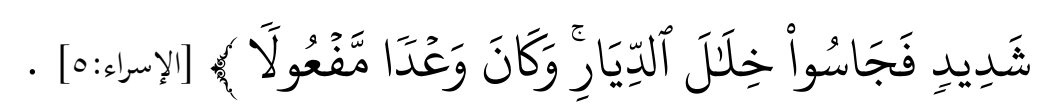

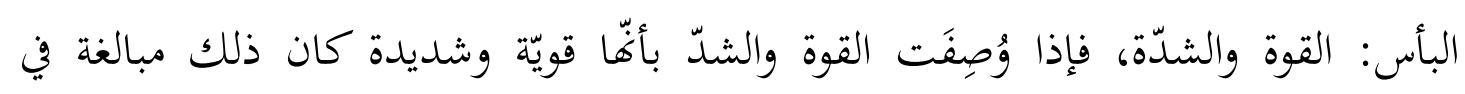

$$
\text { الوصف }
$$

قال الآلوسي: " ومن هنا قيل: إنّ وصف البأس بالشديد مبالغة كأنه قيل: ذوي شدّةٍ شديدة كظِلِّ ظليلٍ ولا بأس فيه، وقيل: إنه بحريد، وهو صحيح أيضًا "(r)" .

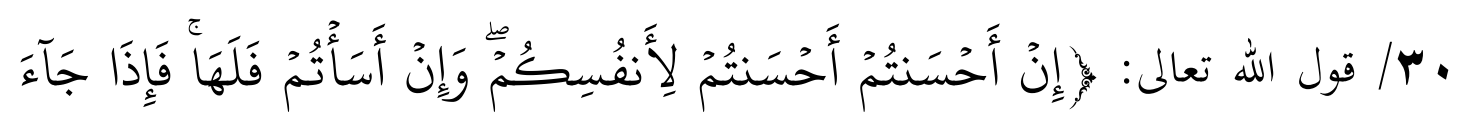

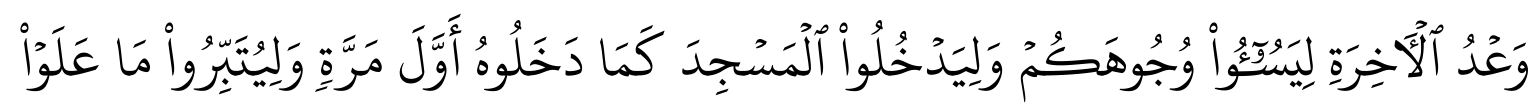

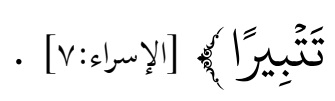

يرى ابن عاشور أنّ الكلام جاء بطريقة التجريد، ولهذا عدّى باللام في الجملتين الأوليين

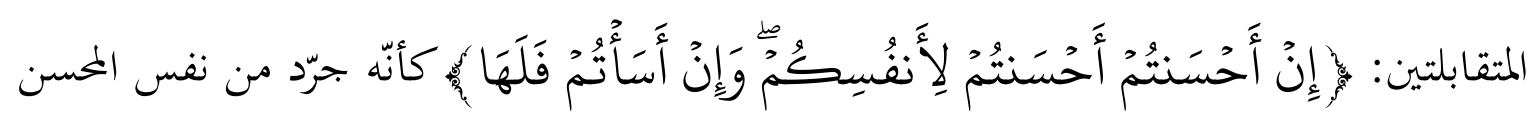

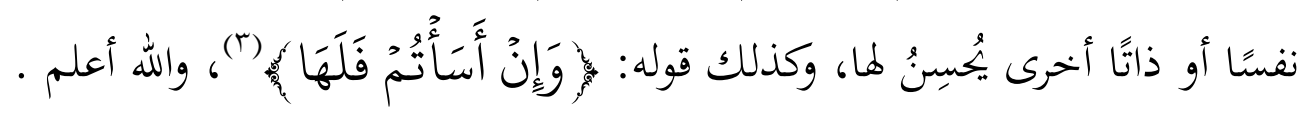

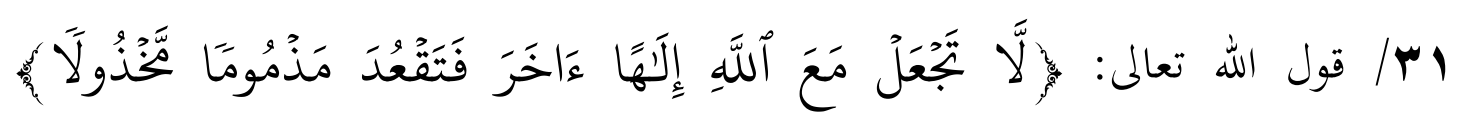
. [الإسراء:rr] القعود هنا بمعنى المكثث(§)، وهو استعارة . 
قال ابن عاشور: " أُرِيد بهذه الاستعارة بتريد معنى النهي إلى أنه في تعريض بالمشركين لأههم

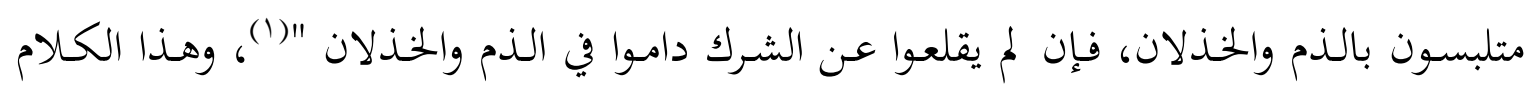

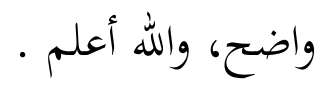

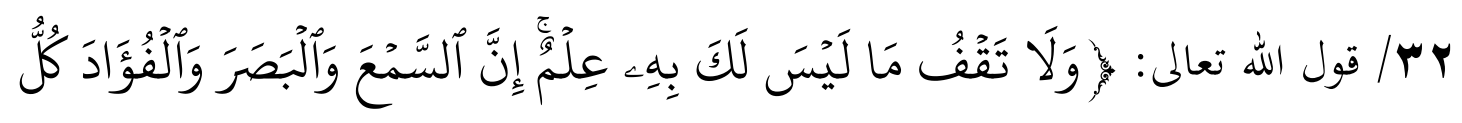

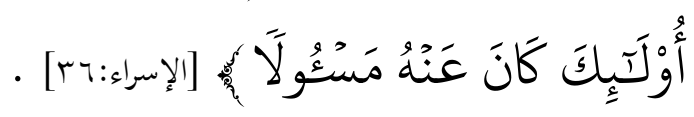

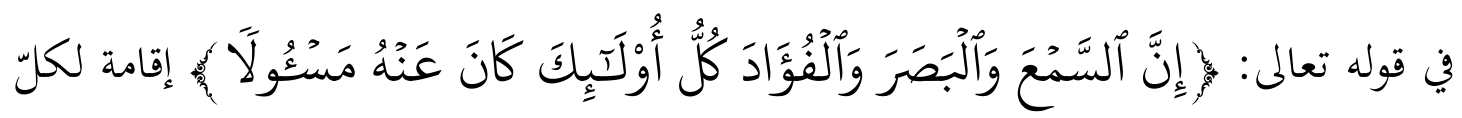

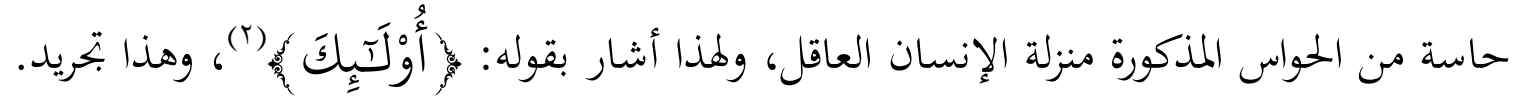
قال ابن عاشور: " وفيه بتريد الإسناد مسؤولا إلى تلك الأشياء بأنّ المقصود سؤال أصحابها،

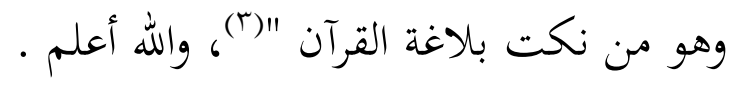

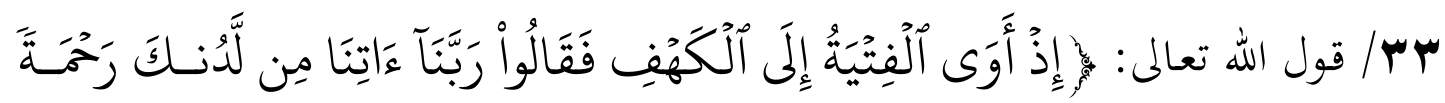

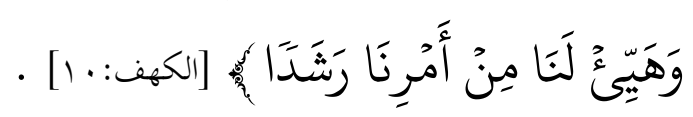

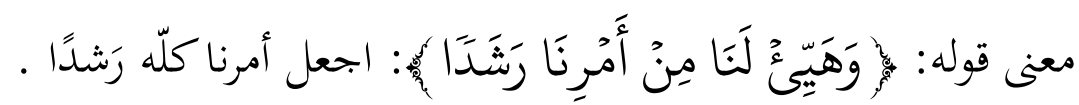

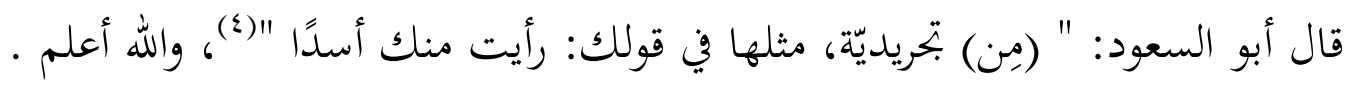




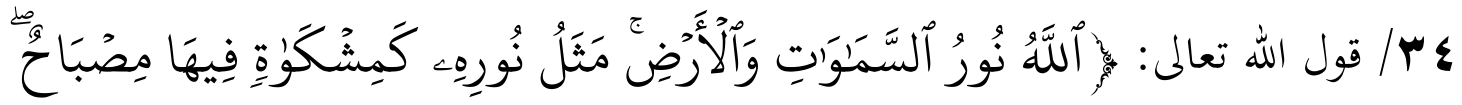

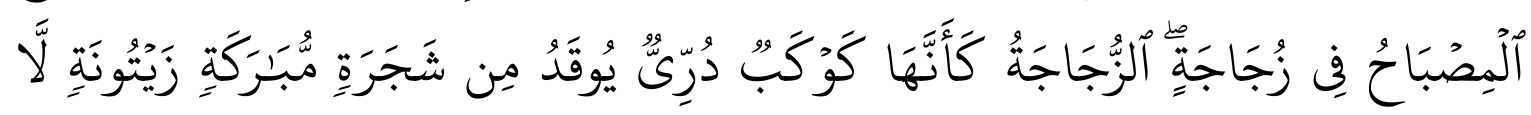

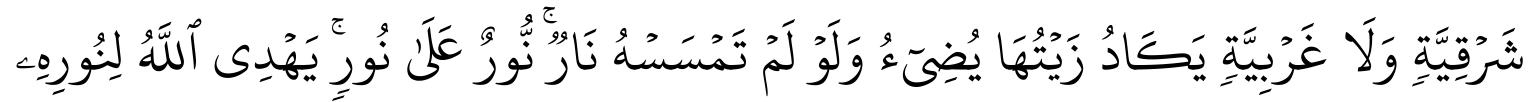

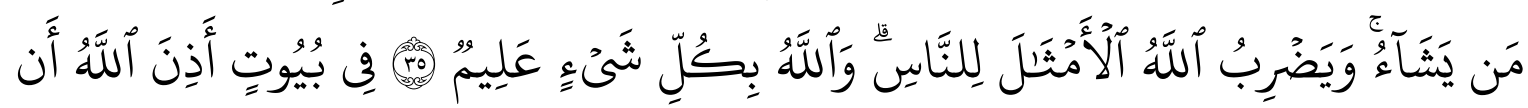

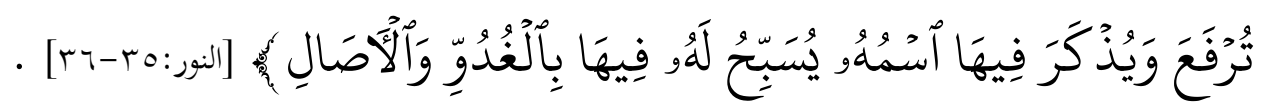

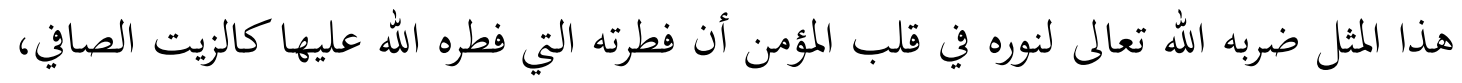

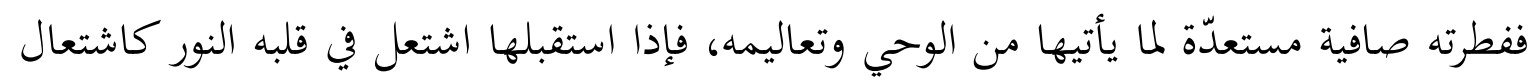

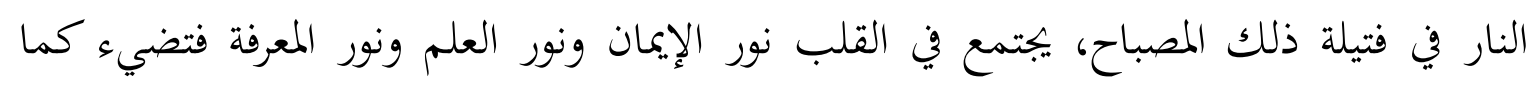
تضيء الزجاجة الدريّة لصفائها) (1) .

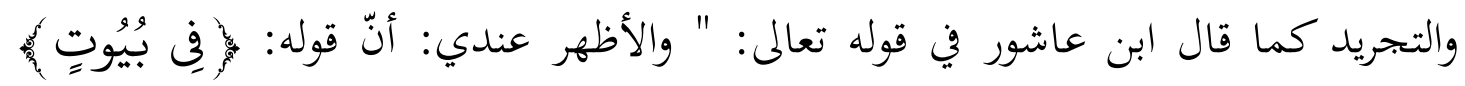

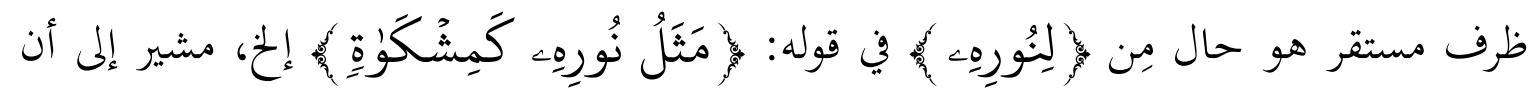

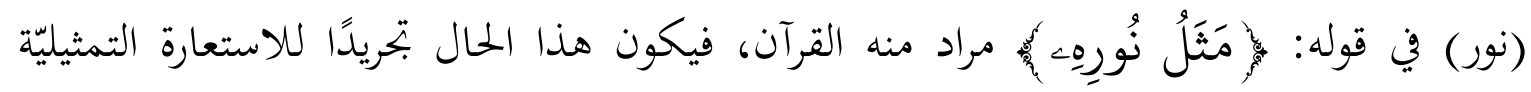
بذكر ما يناسب الميئة المشبهة أعني هيئة تلقّي القرآن وقراءته وتدبّره بين المسلمين منما أشار إليه

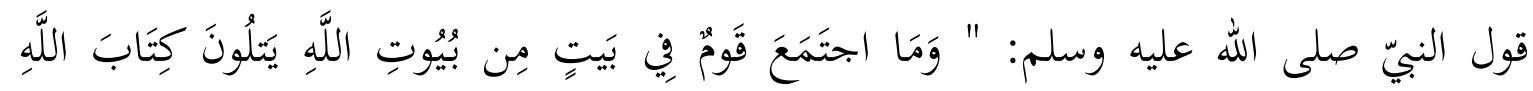

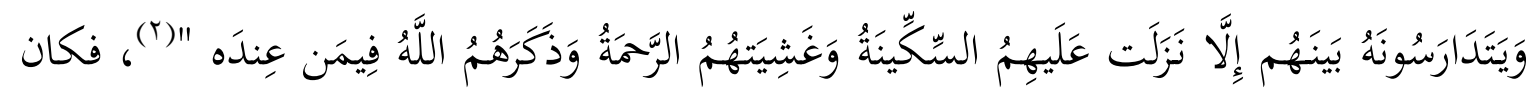

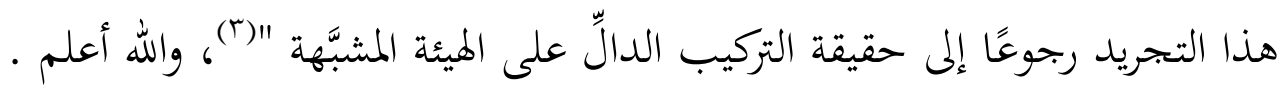

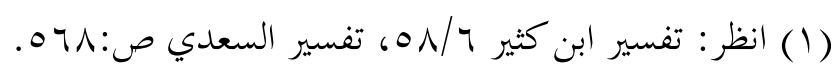

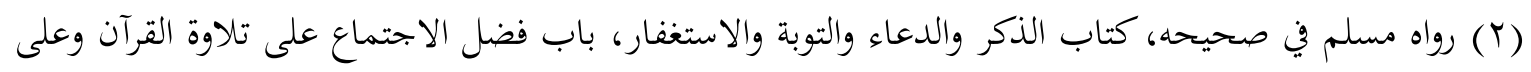




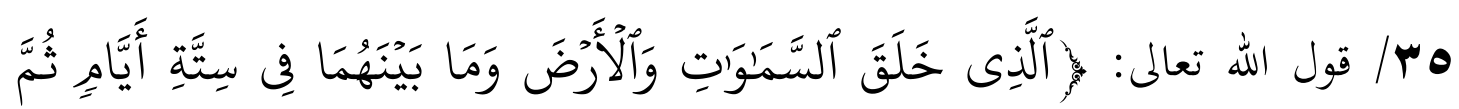

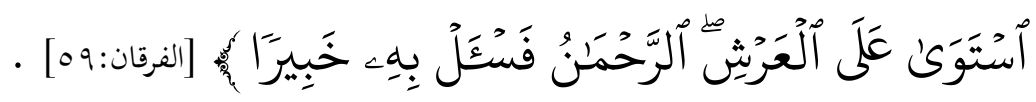

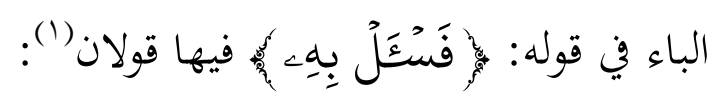

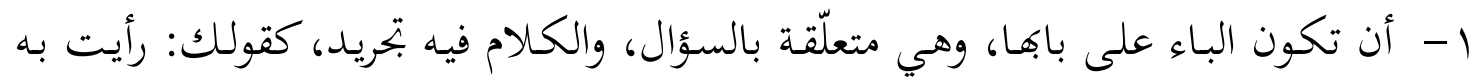

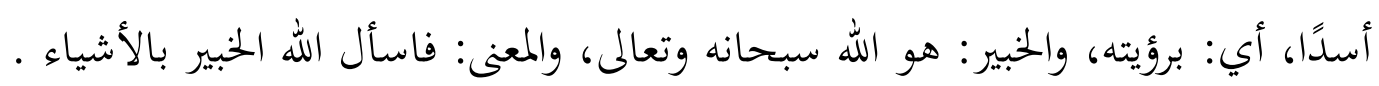

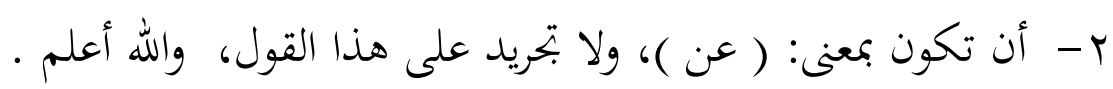

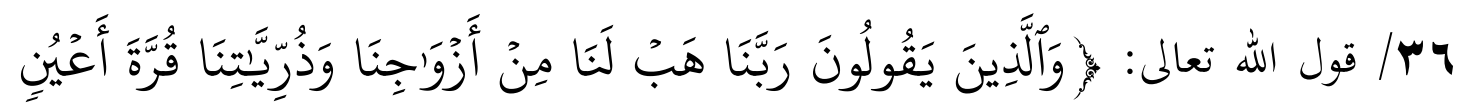

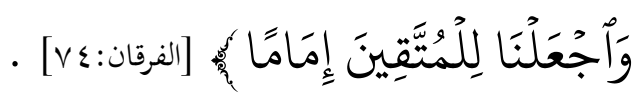

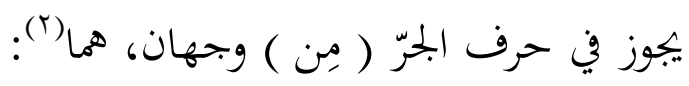

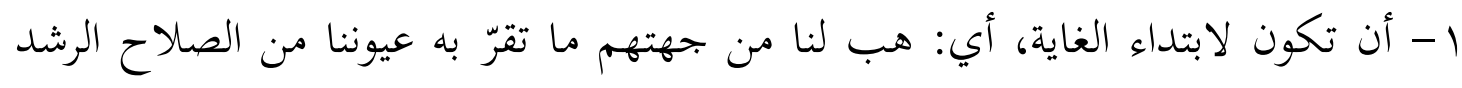

$$
\text { والطاعة . }
$$

r- أن تكون للبيان، أي: يجعلهم الله لهم قرّة أعين، كما تقول: رأيت منك أسدًا، أي: أنت

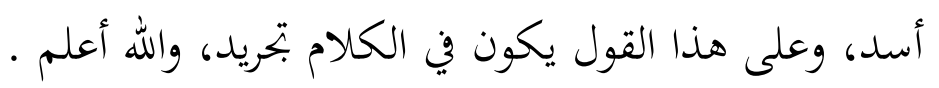

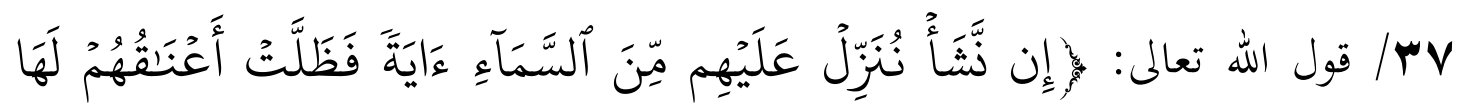

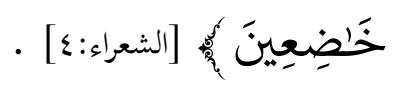

المعنى: إن نشأ نستجب لاقتراحاقم فنزّل عليهم من السماء آية كما سألوا، ولو شئنا لنزلت

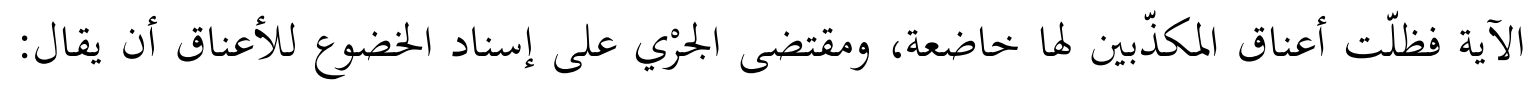

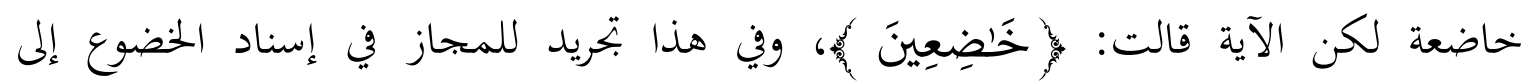

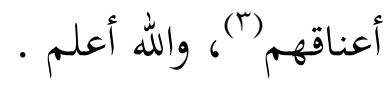

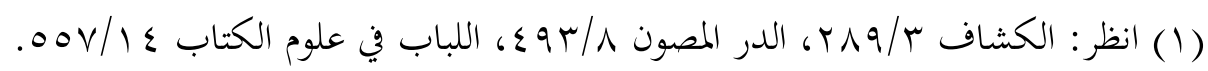

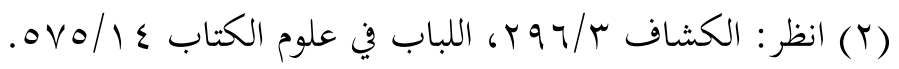

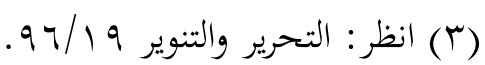




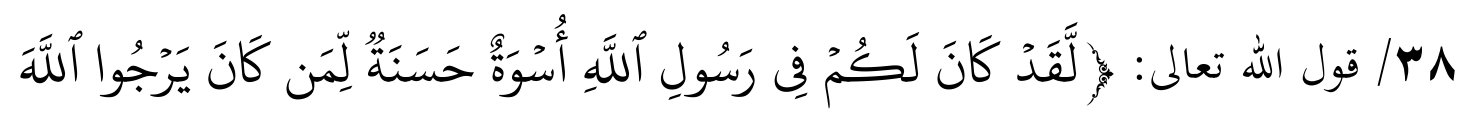

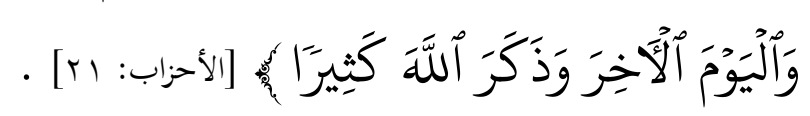

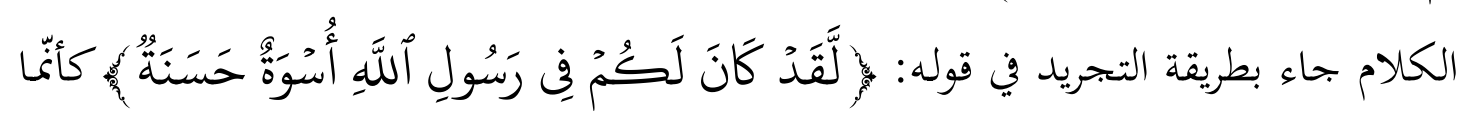

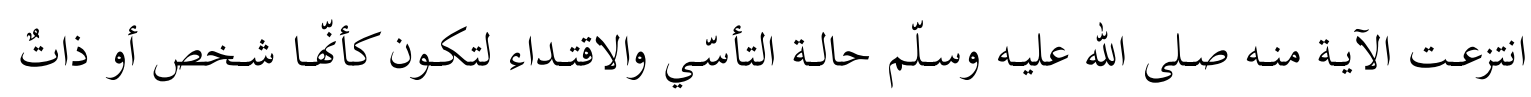

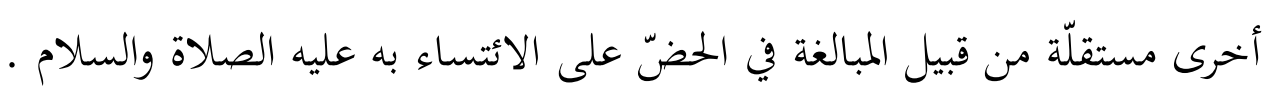

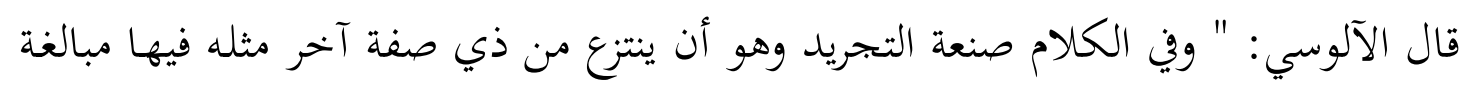

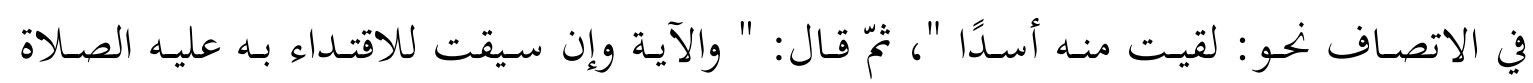

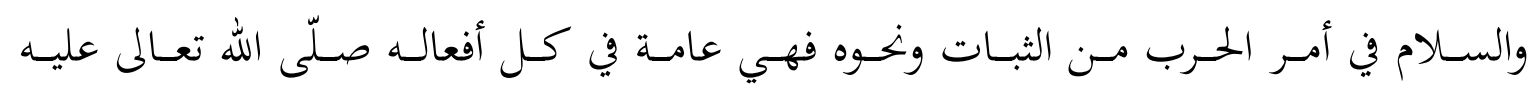
وسلّم "(1)، وهذا الكلام في غاية الحسن، والله أعلم .

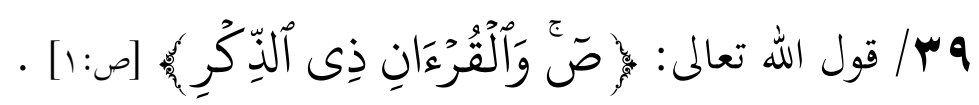

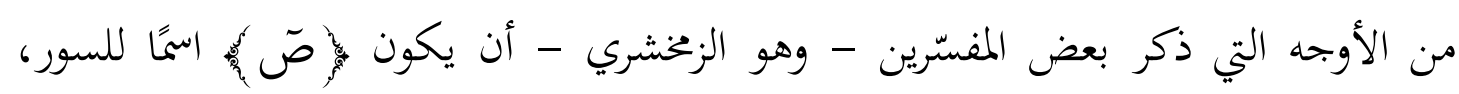

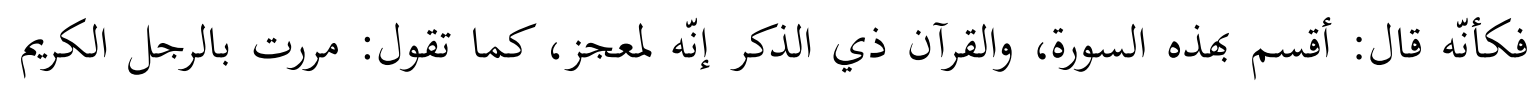

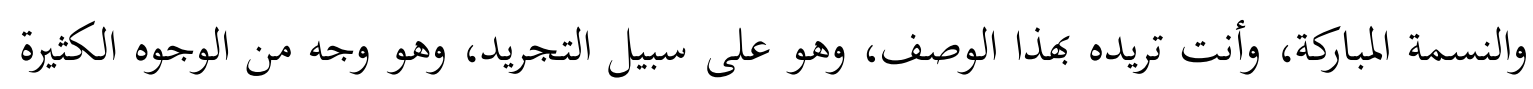

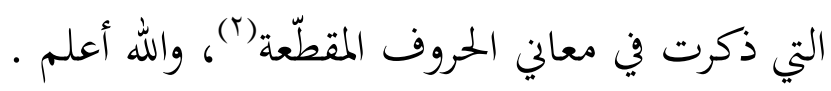

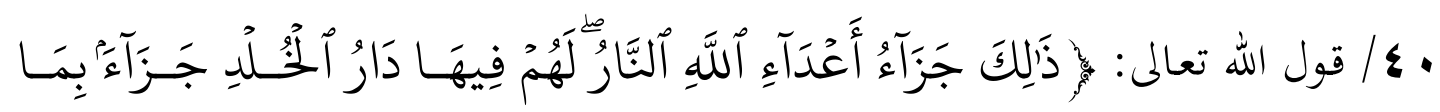

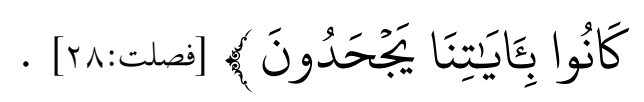

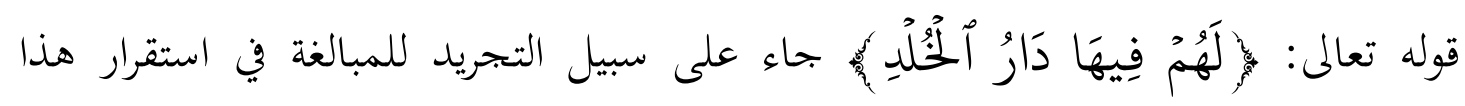

$$
\text { الوصف ودوامه - والعياذ بالله - . }
$$

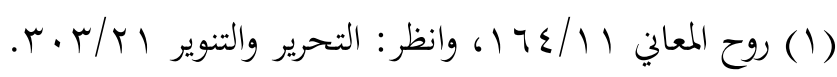

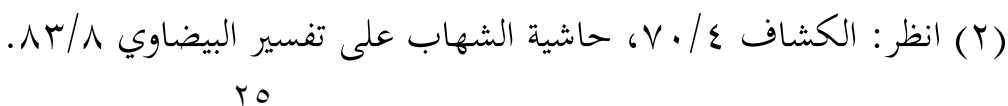


والمعنى: هي لهم دار خلود كما كان لهم في الدنيا دار سرور بمعنى: أهّا كانت لهم نفسها، أي: الدنيا دار لهو وغرور (1)، والله أعلم . مالمبن

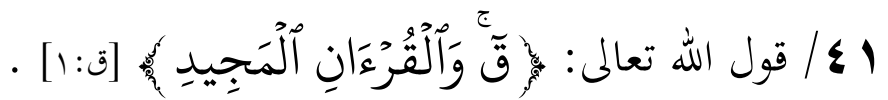

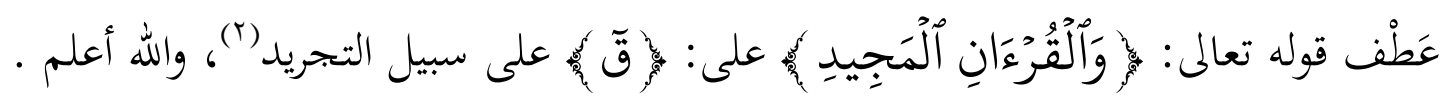

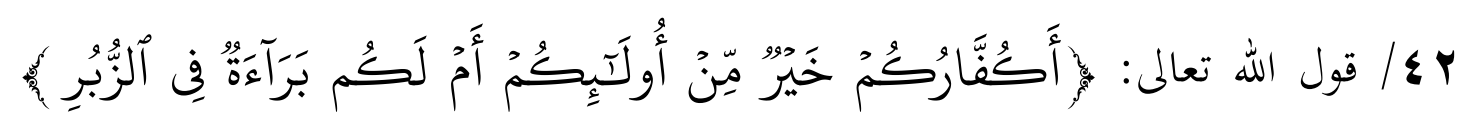

$$
\text { . }[\text { [القمر:r [ }
$$

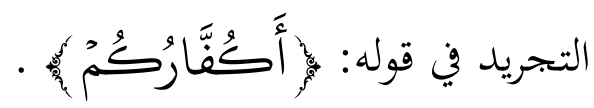

قال الآلوسي: "كأنّه جرَّد منهم كفار وأضيفوا إليهم، وفي ذلك من المبالغة ما فيه، ويجوز أن

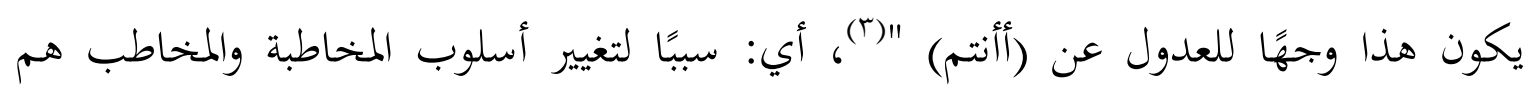
الكفار في مكة، والله اعلم .

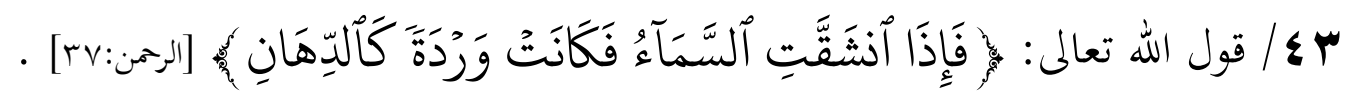

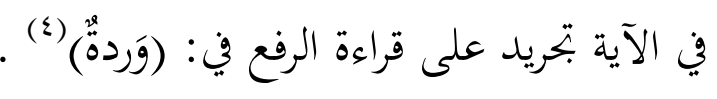

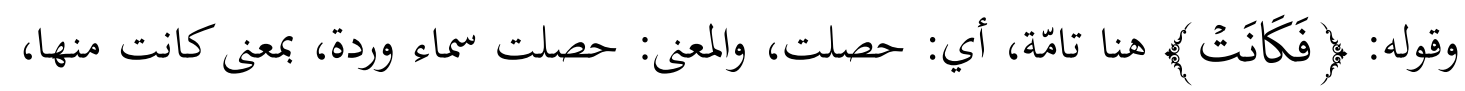

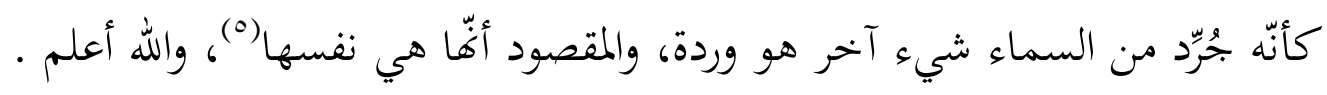

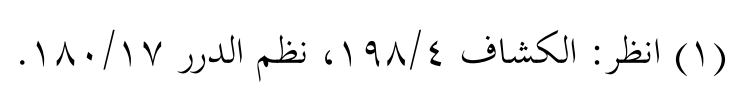

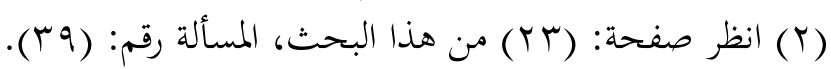

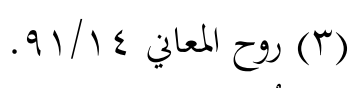

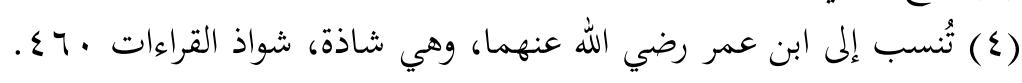

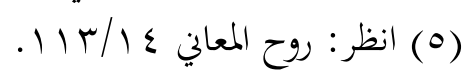




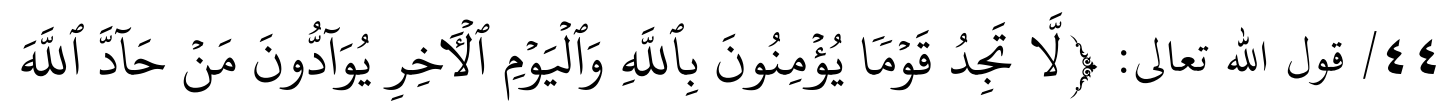

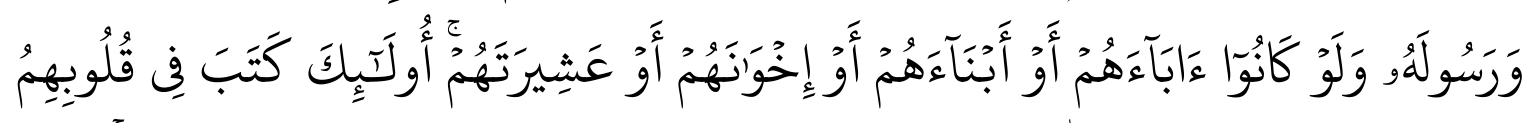

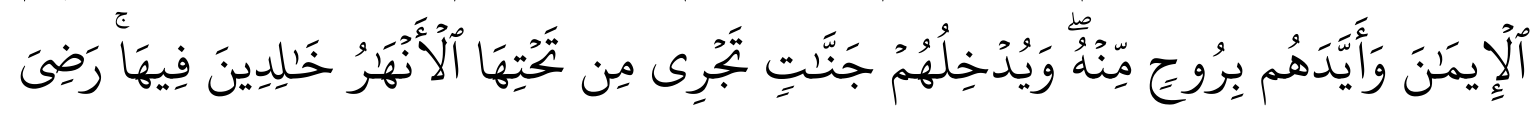

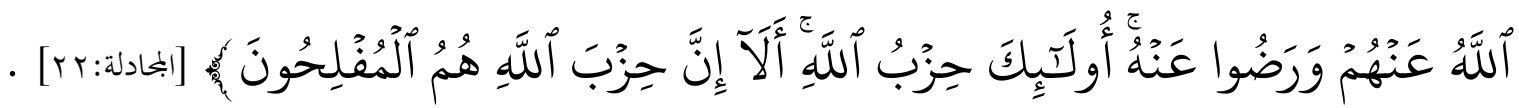

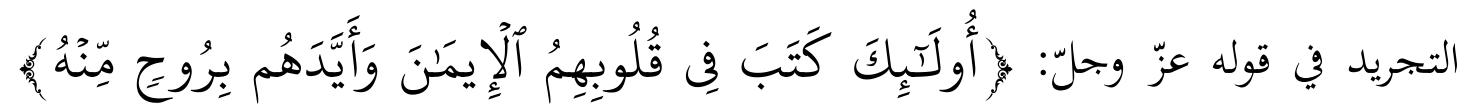

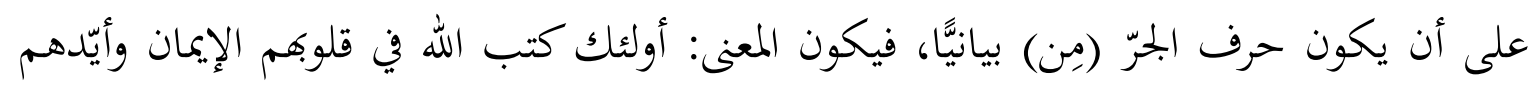

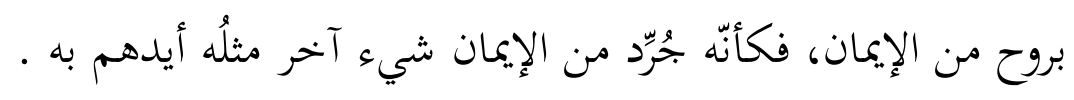

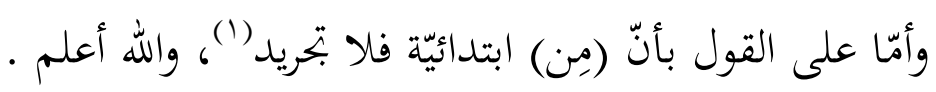

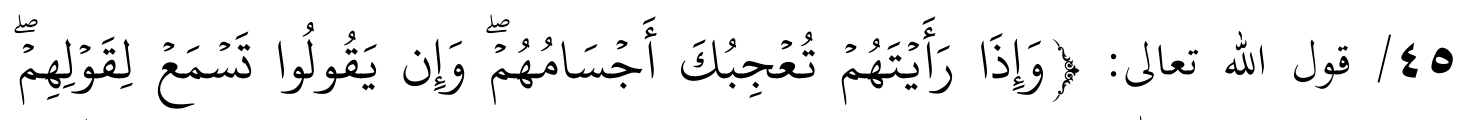

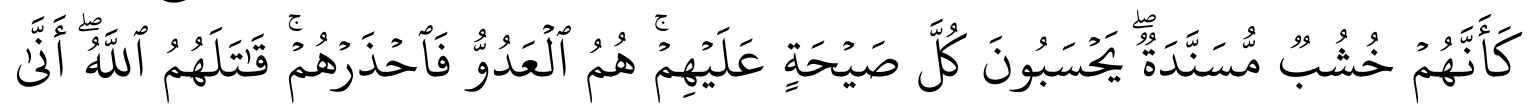

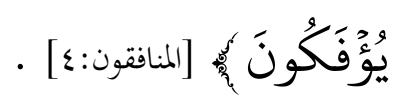

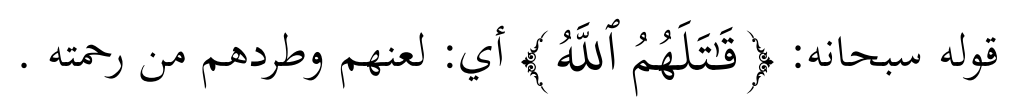

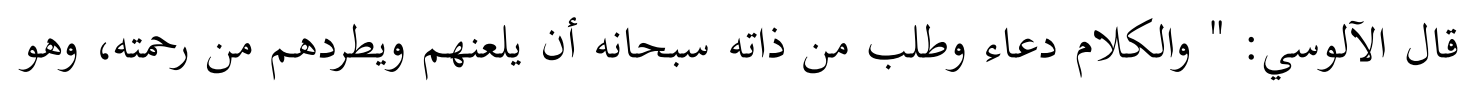

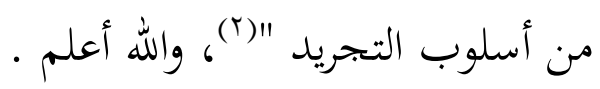




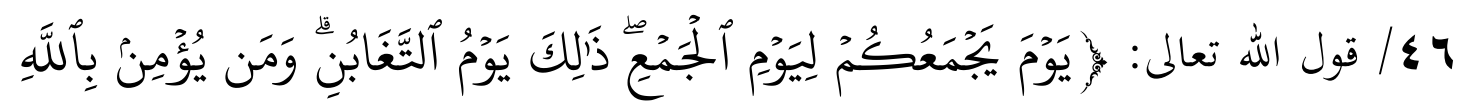

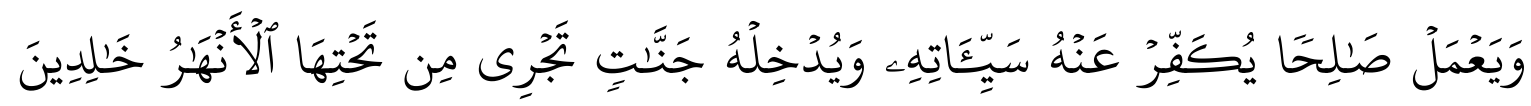

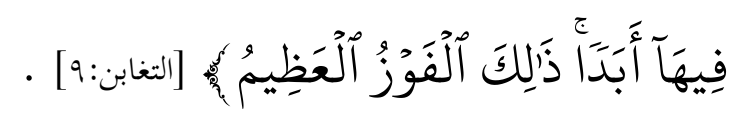

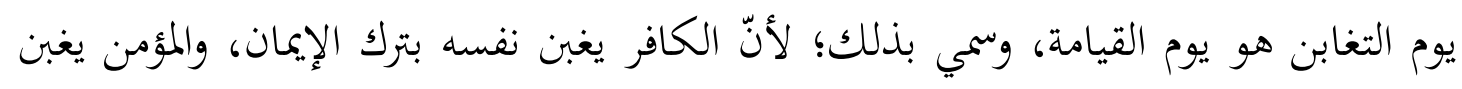

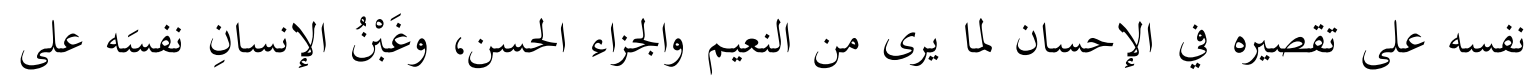

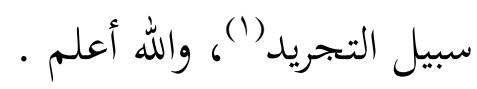

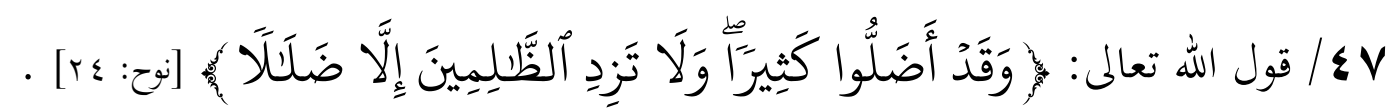

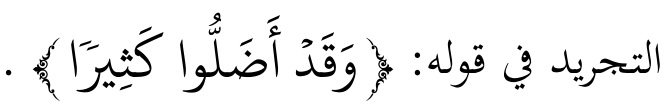

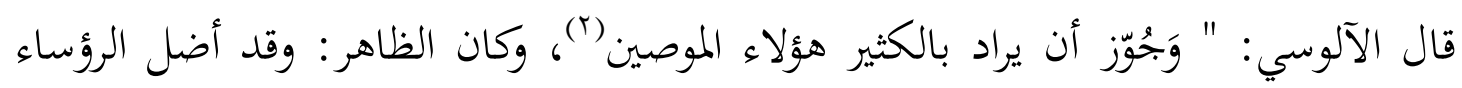

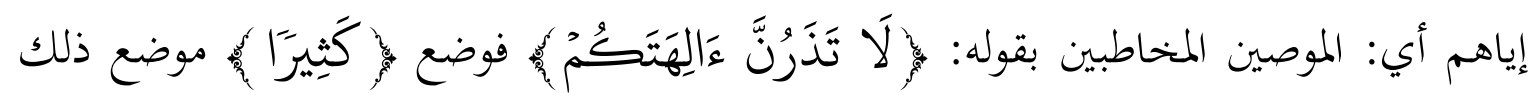

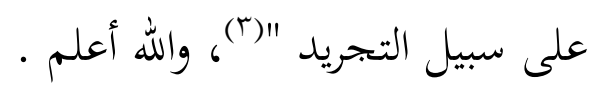

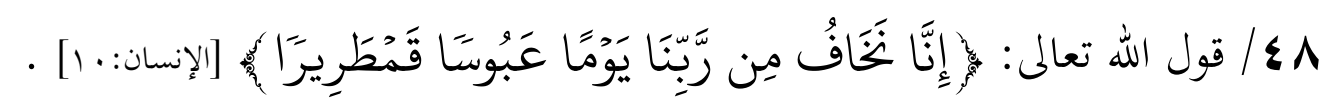

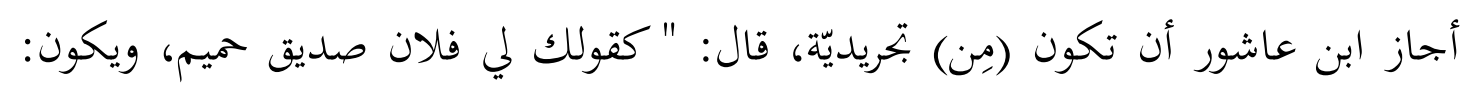

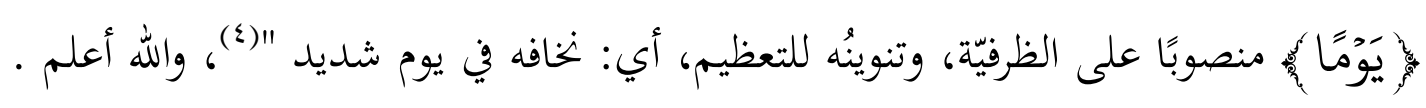

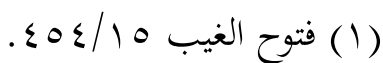

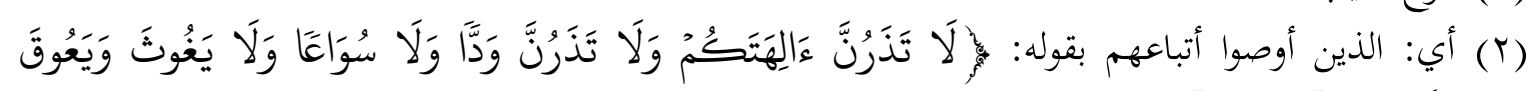

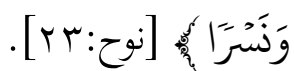

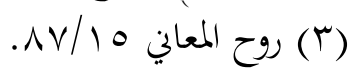

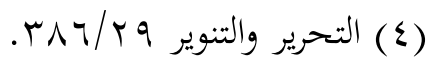




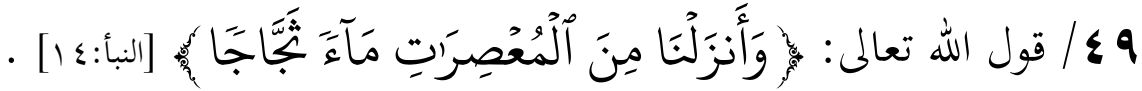

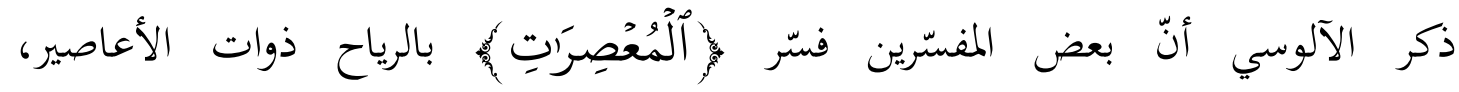

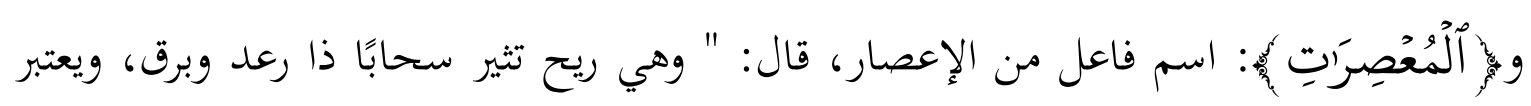

$$
\text { التجريد عليه" (1) }
$$

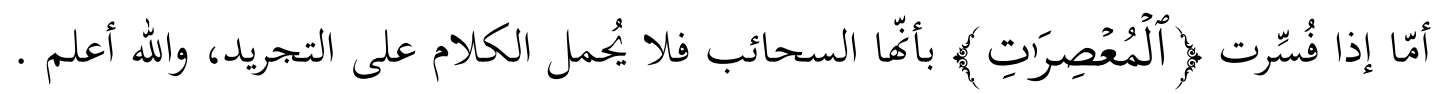

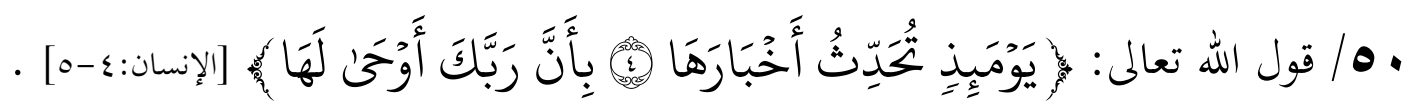

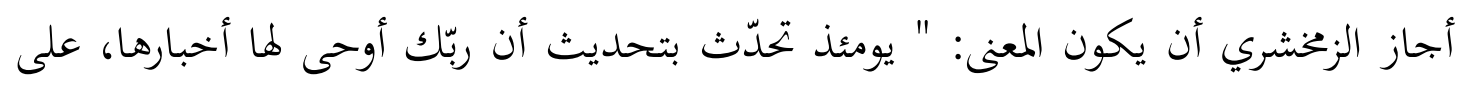

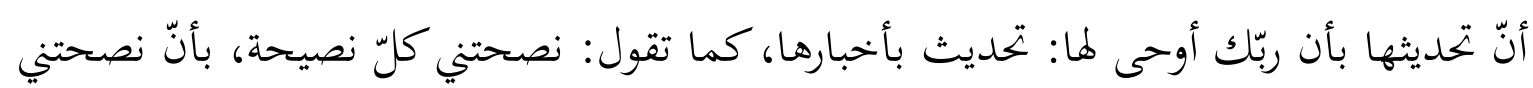

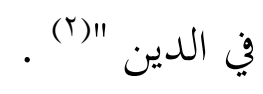

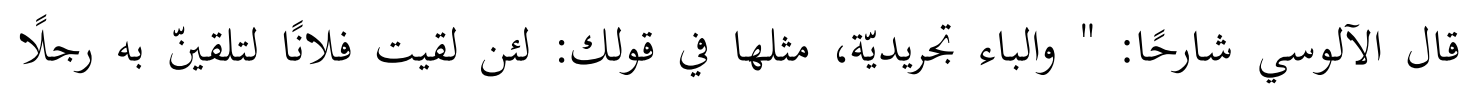

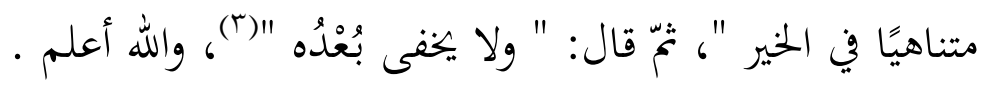

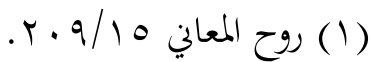

$$
\begin{aligned}
& \text {. } \\
& \text { (T) روح المعاني } 0 \text { (T) }
\end{aligned}
$$




\section{الخحاتمــة}

وفيها أبرز النتائج والتوصيات:

1- بلغ عدد المواضع التي قمت بدراستها خمسين موضعًا، وهي على سبيل الاختيار لا لا سبيل الاستقراء.

r- - ينبي للقارئ أن يهرّر معنى التجريد البديعي حتى يميّزه عن غيره؛ لأنّ هذا المصطلح يرد عند المفسّرين بأكثر من معنى، وقد يأتي بمعناه اللغوي دون الاصطلاحي .

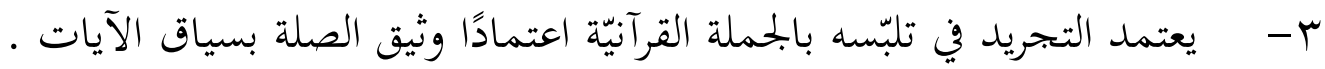
ع - قد يرد التجريد مشارًا إلى معناه وقيمته البلاغيّة من غير تسميته عند بعض المفسّرين

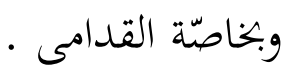

ه - - وجود التجريد عند بعض المفسّرين القدامى باسمه المعروف كالزجاج وغيره .

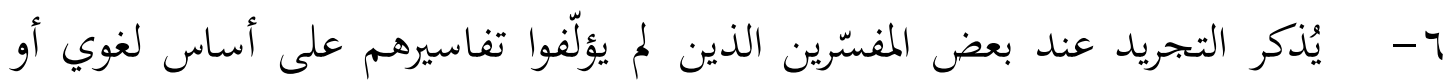

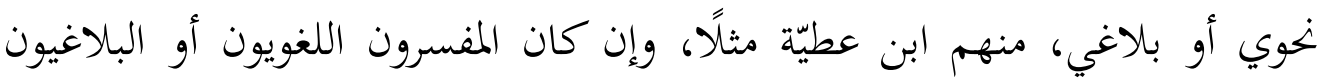
عنوا به أكثر من غيرهم كالزخششري والآلوسي . -V - ربما تعدّدت المصطلحات اللغويّة أو البلاغيّة للأسلوب الواحد أو بتحتمع في جملة واحدة، فتعدّد الفوائد والنكت البلاغيّة ولا تتعارض . 1- - كتب التفسير مناجم مليئة بالكنوز اللغويّة والبلاغيّة والعلميّة التي لا تفنى مع كثرة

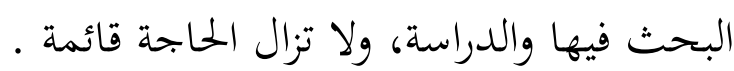

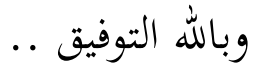
وصلى الله وسلّم على سيّدنا ونبيّنا محمد وعلى آله وصحبه أجمعين . 


\section{المصادر والمراجع}

- إرشاد العقل السليم إلى مزايا الكتاب الكريم، لأبي السعود محمد بن محمد بن مصطفى

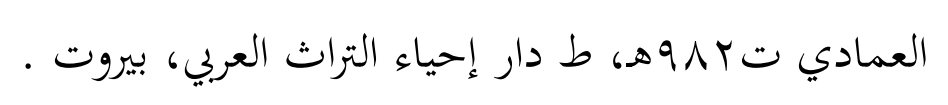

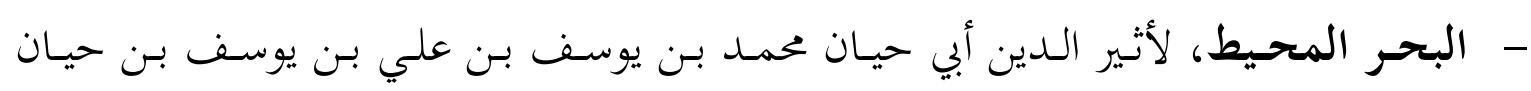

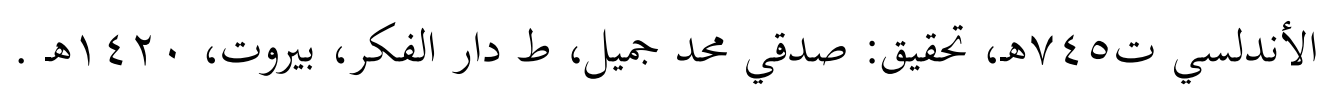

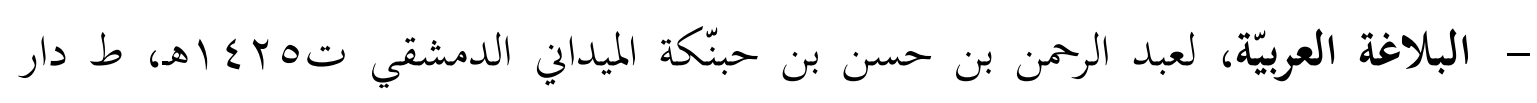

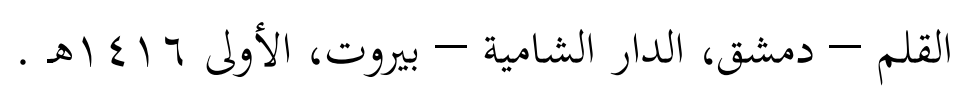

- التجريد؛ بلاغته وأساليبه في القرآن المجيد، لـ د عامر بن عبد الله الثبيتي، بحلة الجحامعة

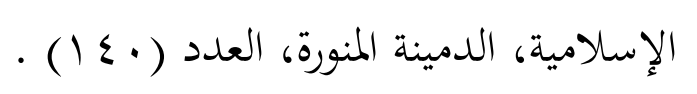

- التحرير والتنوير = تحرير المعنى السديد وتنوير العقل الجلديد من تفسير الكتاب البحيد، للإمام

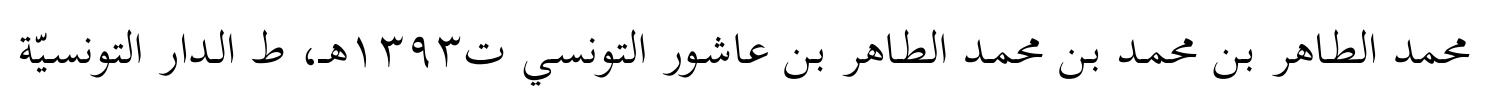

$$
\text { للنشر - تونس ع } 919 \text { اهـ . }
$$

- التسهيل لعلوم التنزيل، لأبي القاسم محمد بن احمد بن محمد بن عبد الله ابن جزي الكلبي

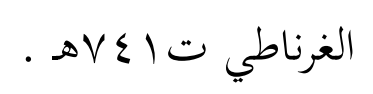

- تفسير القرآن العظيم، لأبي الفداء إسماعيل بن عمر بن كثير القرشي البصري ثم الدمشقي

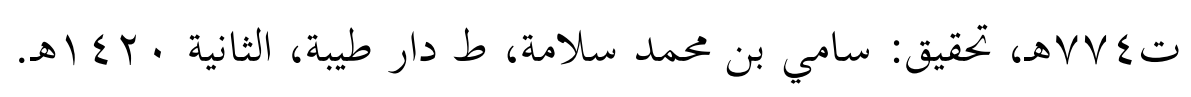

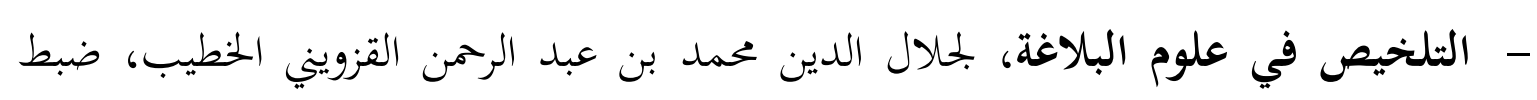

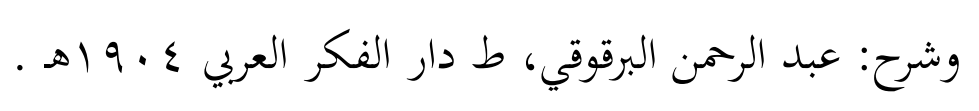

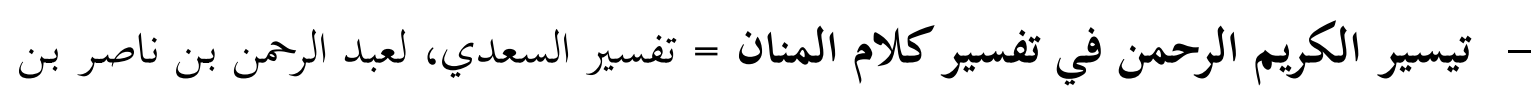

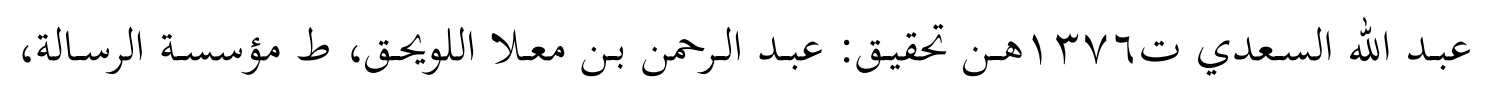

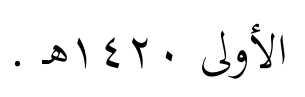

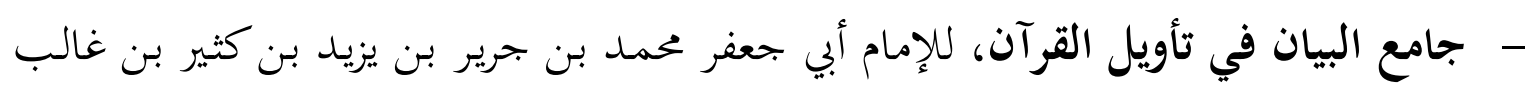

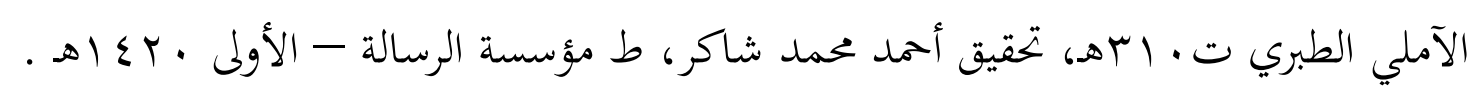

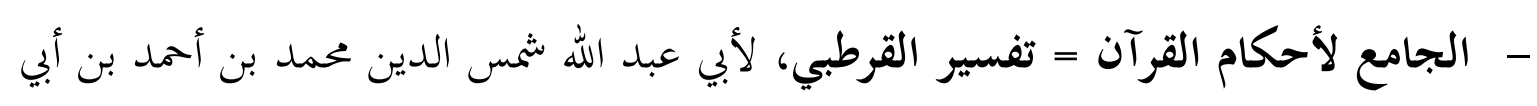


بكر بن فرح الأنصاري الخزرجي القرطبي ت الجاهـ، تحقيق: أحمد البردوني وإبراهيم أطفيش،

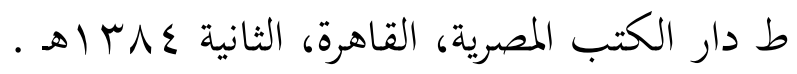
- - حاشية الشهاب على تفسير البيضاوي المسمّاة: عناية القاضي وكفاية الراضي على تفسير

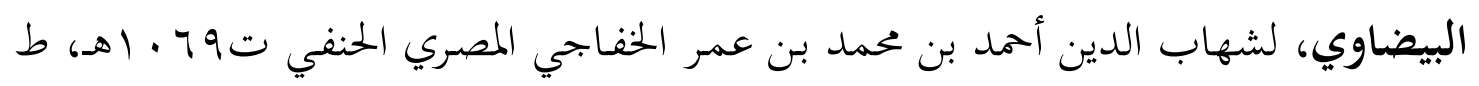
دار صادر، بيروت . - الدر المصون في علوم الكتاب المكنون، لأبي العباس شهاب الدين أحمد بن يوسف بن

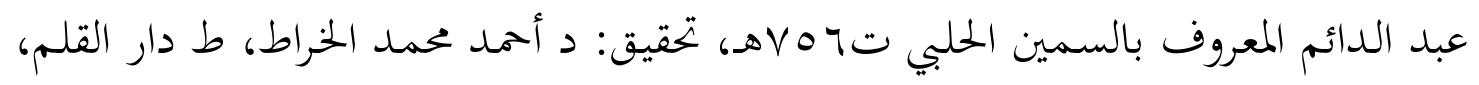

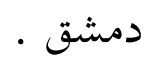
- ديوان الأعشى، شرح وضبط وتقديم: د عمر فاروق الطباع، ط دار القلم للطباعة والنشر والتوزيع، لبنان .

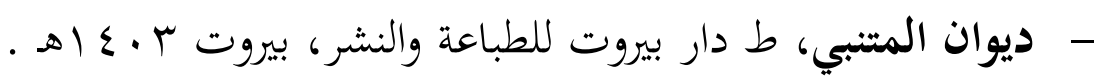

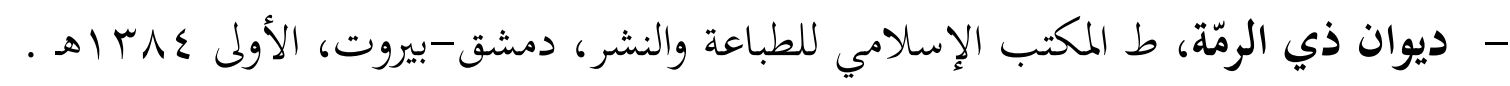

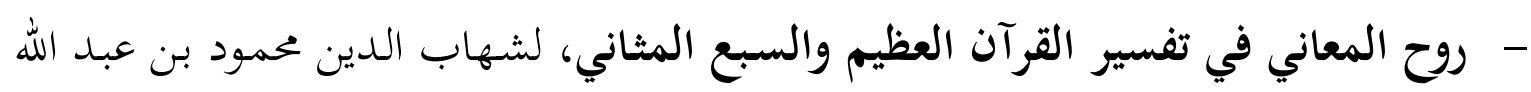

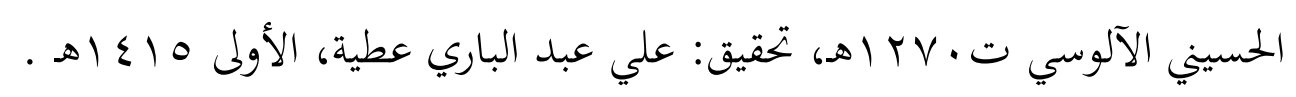

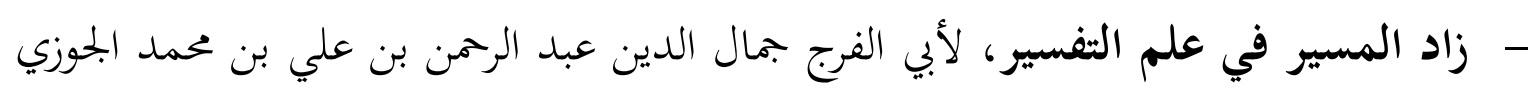

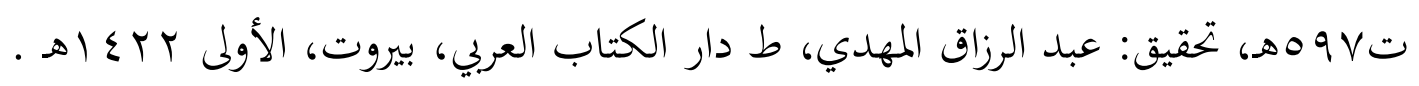
- السنن الكبرى، لأبي بكر أحمد بن الحسين بن علي بن موسى الحُسَروجِردي الخراساني البيهقي تمهـهـ، تحقيق: محمد عبد القادر عطا، ط دار الكتب العلمية، لبنان، الثالثة . $ه \leqslant Y \leqslant$ - شرح الكافية الشافية، لأبي عبد الله جمال الدين محمد بن عبد الله ابن مالك الطائي الجيّيّاني

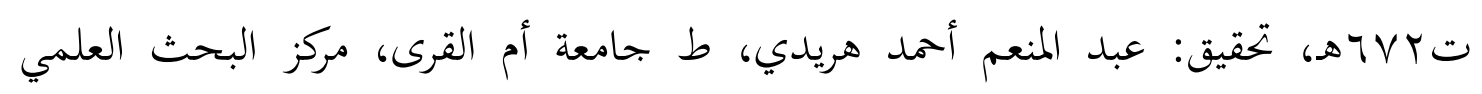
وإحياء التراث الإسلامي، الأولى .

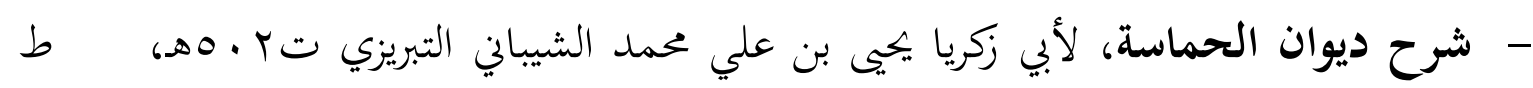

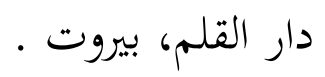

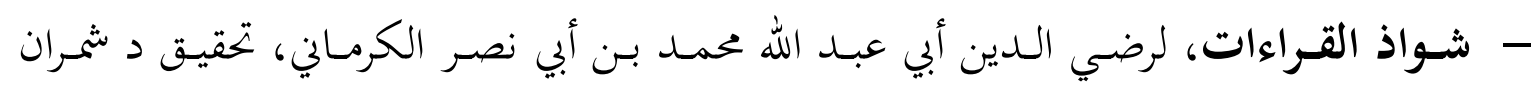

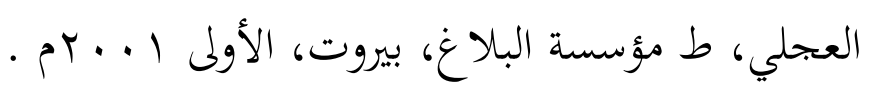


- صحيح البخاري = الجامع المسند الصحيح المختصر من أمور رسول الله صلى الله عليه

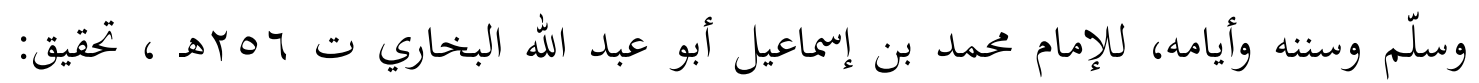

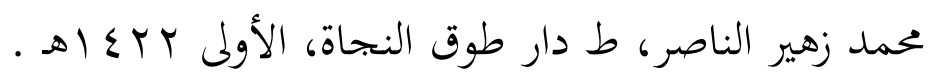
- صحيح مسلم = المسند الصحيح المختصر بنقل العدل عن العدل إلى رسول الله صلى الله اله

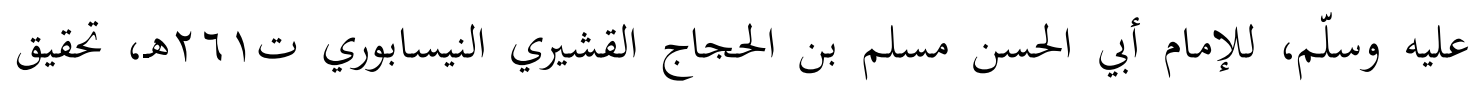

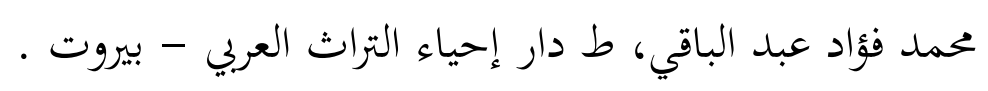
- الطراز لأسرار البلاغة وعلوم حقائق الإعجاز، ليحيى بن حمزة بن علي بن إبراهيم الحسيني

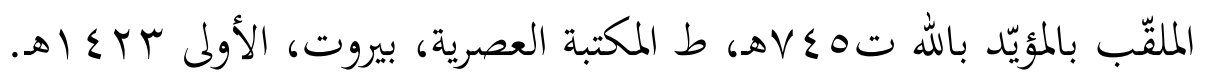
- علم البديع، لـ د عبد العزيز عتيق، ط دار النهضة العربية، بيروت . - غرائب القرآن ورغائب الفرقان، لنظام الدين الحسين بن محمد بن حسين القمي النيسابوري

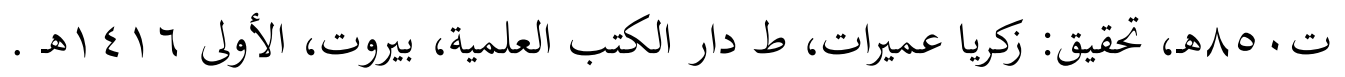
- فتوح الغيب في الكشف عن قناع الريب = حاشية الطيبي على الكشاف، لشرف الدين

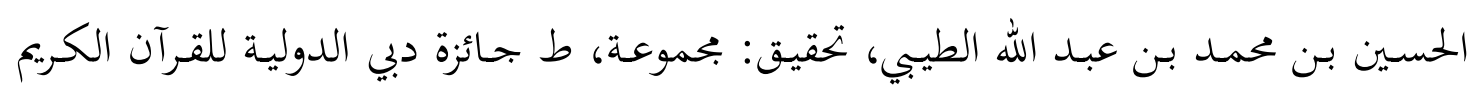
. .0 - الكثّاف عن حقائق غوامض التنزيل، للإمام أبي القاسم جار الله محمود بن عمرو بن أحمد

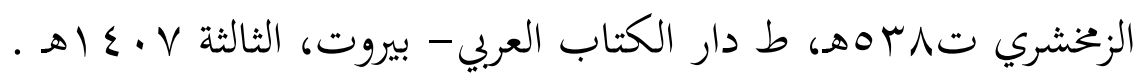

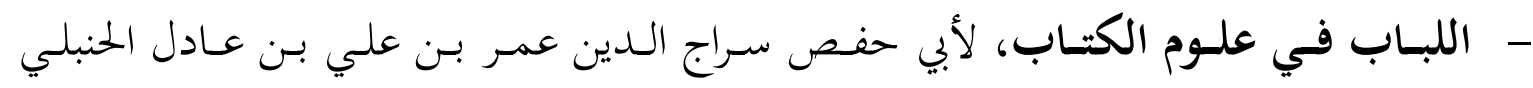

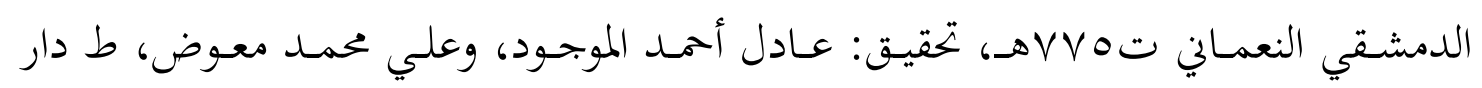

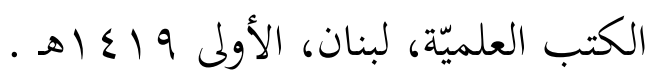

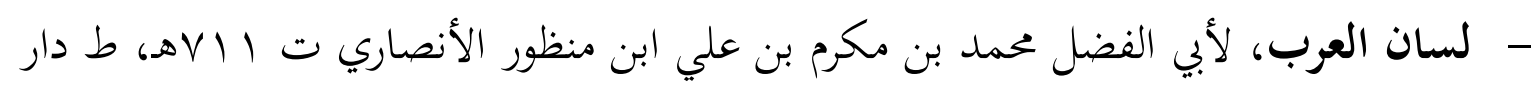

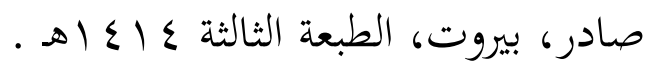

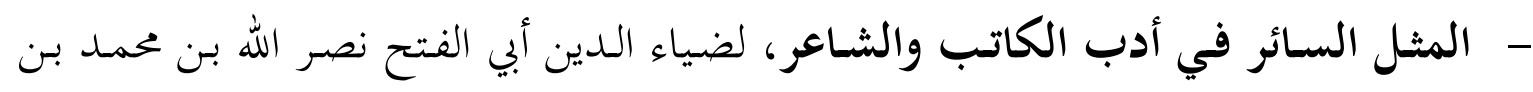

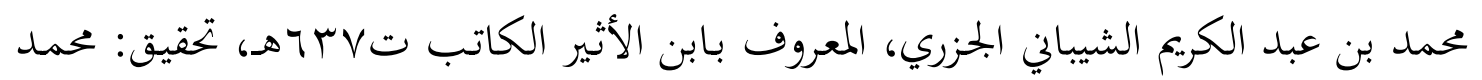

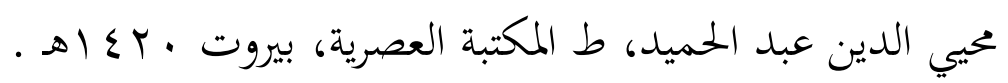


- المحرر الوجيز في تفسير الكتاب العزيز، لأبي محمد عبد الحق بن غالب بن عبد الرحمن

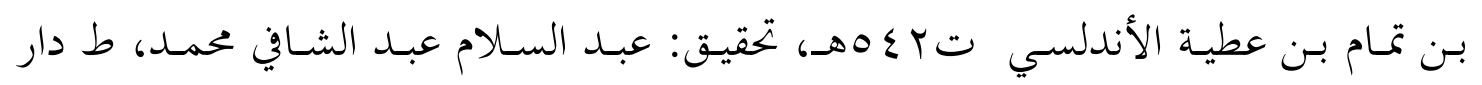

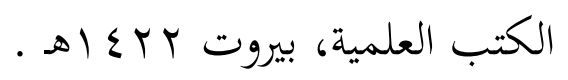

- مـدارك التنزيل وحقائق التأويـل، لأبي البركات عبـد الله بـن أحمد بـن محمود حـافظ الدين

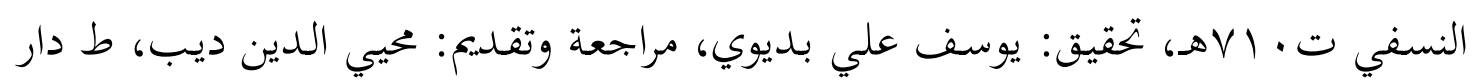

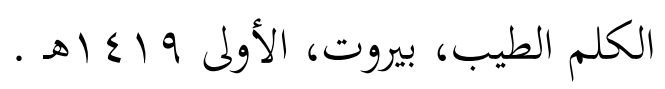

- المصنف، لأبي بكر عبد الرزاق بن هام بن نافع الحميري الصنعاني ت البالهـ، تحقيق:

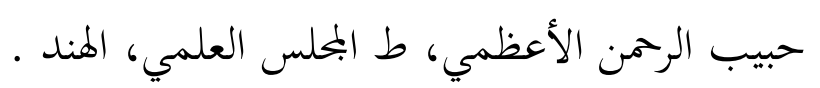

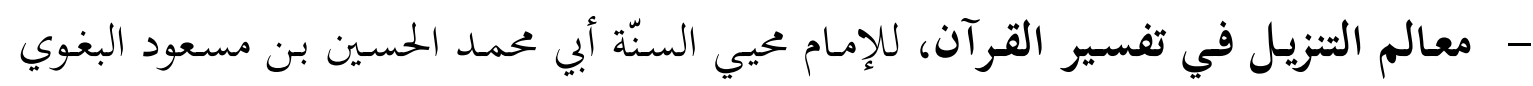

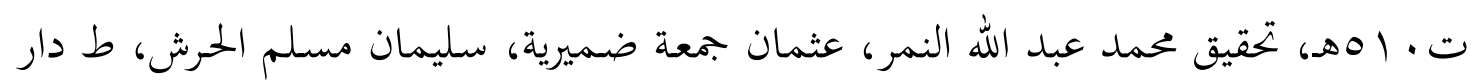

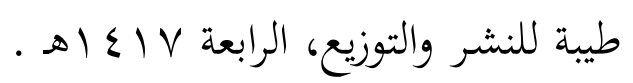

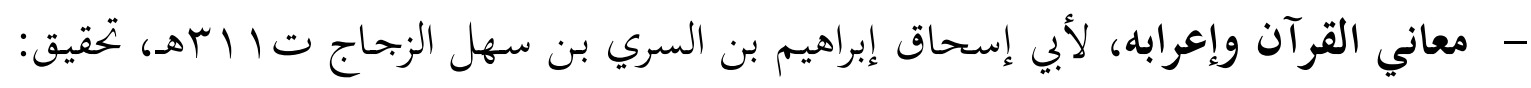

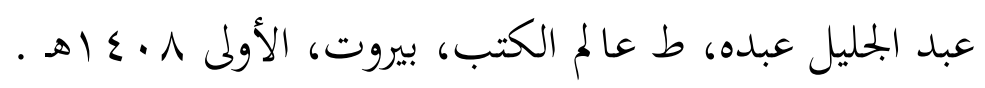

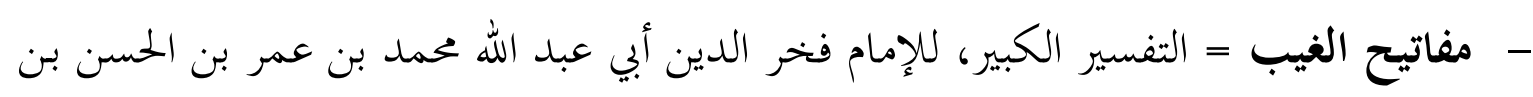

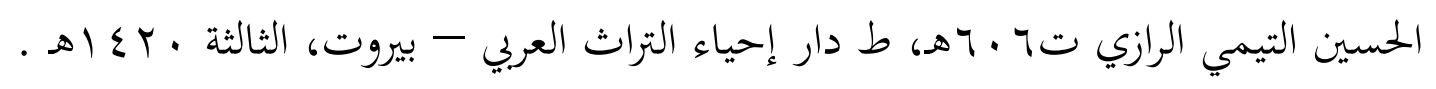
- النشر في القراءات العشر، لأبي الخير شنمس الدين محمد بن محمد بن يوسف ابن الجزري ت بrمهـ، تحقيق: علي محمد الضباع، ط المطبعة التجارية الكبرى .

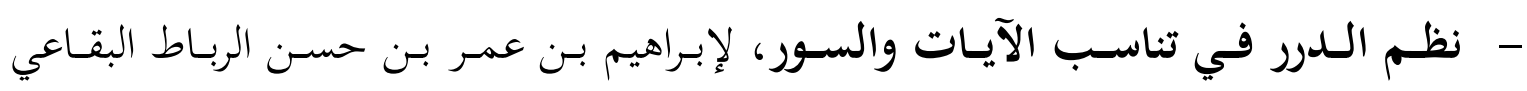

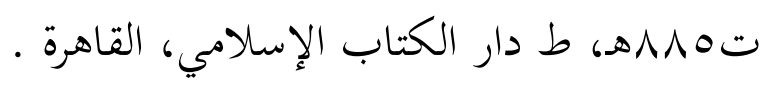




\section{فهرس الموضوعات}

\begin{tabular}{|c|c|c|}
\hline الصفحة & 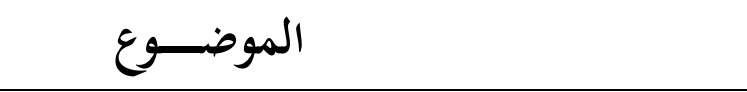 & b \\
\hline 1 & ملخص البحث & 1 \\
\hline r & ملخص البحث بالإنجليزية & r \\
\hline$\mu$ & المقدّمة & $\mu$ \\
\hline$\varepsilon$ & تعريف (التجريد) لغةً واصطلاحًا & $\varepsilon$ \\
\hline V & قيمة التجريد الباغيّة & 0 \\
\hline$\Lambda$ & علاقة التجريد بالقرآن الكريم & 7 \\
\hline 9 & الدراسة التطبيقيّة للتجريد في القرآن الكريم & V \\
\hline r. & الخحاتمة & $\Lambda$ \\
\hline$M$ & المصادر والمراجع & 9 \\
\hline ro & فهرس الموضوعات & 1 . \\
\hline
\end{tabular}

